\title{
IMAGEN Y PROPAGANDA EN LAS PRIMERAS AMONEDACIONES DEL REY DE ARAGÓN ${ }^{1}$
}

\author{
IMAGE AND PROPAGANDA IN THE FIRST COINS \\ OF THE KING OF ARAGON
}

\author{
MARTA SERRANO COLL \\ Universitat Rovira i Virgili - TEMPLA
}

\begin{abstract}
Resumen: Este estudio analiza parte del repertorio iconográfico que contribuyó a reafirmar y fortalecer el poder real de uno de los más emblemáticos reyes de Aragón de finales del siglo XI: Sancho Ramírez. Además de profundizar sobre las efigies estampadas en sus primeras monedas, efectivo vehículo de propaganda, se abordará otro elemento que alcanzó una trascendencia simbólica sólo explicable en relación con esta regia institución que, a su vez, la promocionaba: la cruz, que ahora se convertirá en elemento de proclamación monárquica. Además de examinar las motivaciones políticas que subyacen bajo estas representaciones, se evidenciará la relevancia del condado de Urgell y, en relación con él, la personalidad de doña Sancha, sobre la que tanto merecería profundizar.
\end{abstract}

Palabras clave: Sancho Ramírez; doña Sancha; numismática; cruz procesional; árbol de la vida; crismón; Santa Cruz de la Serós; románico aragonés; iconografía del rey.

\begin{abstract}
This study analyzes aspects of the iconographic repertoire that contributed to reaffirm and strengthen the royal power of one of the most emblematic kings of Aragon of the late eleventh century: Sancho Ramírez. The effigies stamped on his first coins, which should be considered among his most effective propaganda vehicles, will be studied, as will an element that reached a symbolic significance only understandable in relation to the royal institution that, in turn, promoted it: the cross, now developed as the clearest element of monarchical proclamation. In addition to considering the political motivations that lie beneath these representations, the relevance of the county of Urgell will be discussed and, in connection with it, Doña Sancha, a figure worthy of deeper investigation.
\end{abstract}

Keywords: Sancho Ramírez; doña Sancha; numismatics; processional cross; tree of life; chrismon; Santa Cruz de la Serós; Aragonese romanesque art; royal iconography.

${ }^{1}$ Este artículo se enmarca dentro del Proyecto de Investigación liderado por Javier Martínez de Aguirre Arte y Monarquía en el Nacimiento y Consolidación del reino de Aragón (10351134) [HAR2009-08110]. Aprovecho estas líneas para agradecer a Javier Martínez de Aguirre, David Simon y Francisco de Asís García su tiempo; sus observaciones han permitido perfilar mejor algunas de las ideas aquí expuestas. 


\section{SUMARIO}

1. Introducción.- 2. Los mancusos: la adopción de una moneda foránea y las primeras emisiones cristianas.- 3. Sancho Ramírez y las primeras emisiones de vellón.3.1. Las particularidades del anverso: el busto de perfil.- 3.2. Las particularidades del reverso: la cruz sobre vástago.- 4 . La cruz y su vínculo con la casa real de Aragón.4.1. La ceremonia de coronación: el rey como Miles Dei.-4.2. La iconografía como elemento documental.- 4.3. La advocación a la Santa Cruz.- 5. Bibliografía citada.

\section{INTRODUCCIÓN}

Con clara intención legitimadora, el rey Sancho Ramírez inició una política propagandística en distintos soportes, entre ellos el de la acunación de moneda, iniciativa, la de la emisión monetaria en la Península en el siglo XI, cuya importancia conviene destacar aquí pero que se valorará más adelante. De entre todos los tipos que batió destacan los problemáticos mancusos y las variadas emisiones de vellón, que tomaron como modelo emisiones peninsulares y ultrapirenaicas. Si los anversos presentan una serie de iconografías que constatan vínculos con territorios más o menos cercanos y que evidencian una voluntad de imitatio y de plasmación de la auctoritas, sus reversos muestran símbolos sacros que, como ahora se verá, no sólo se relacionaron con la monarquía, sino que terminaron por identificarse con ella. Originariamente elementos simbólicos de carácter sagrado, a finales del siglo XI estos elementos alcanzaron tal entidad, e incluso identidad regia, que proclamaban la figura del rey como defensor de la fe cristiana y como gobernante cristianísimo, lo que realzó extraordinariamente la vinculación entre la divinidad y el soberano, que, parece ser, nunca perdió el referente apostólico para sus cometidos. Aunque la numismática se configura como soporte fundamental en el punto de arranque del presente discurso, no se desatenderán otros soportes, como los documentos surgidos de la cancillería, la escultura o también la arquitectura, sea ésta promovida por los soberanos o por algunos miembros de su entorno más inmediato.

\section{LOS MANCUSOS: LA ADOPCIÓN DE UNA MONEDA FORÁNEA Y LAS PRIMERAS EMISIONES CRISTIANAS}

Es un hecho admitido por la historiografía que los condados catalanes se configuraron como los primeros territorios cristianos peninsulares en emitir moneda, en un principio siguiendo modelos carolingios ${ }^{2}$, después conforme a los tipos musulmanes y, ya en la segunda mitad del siglo X, exhibien-

\footnotetext{
${ }^{2}$ Es decir, cruz en anverso y monograma en reverso.
} 
do una riqueza iconográfica extraordinaria, tal y como manifiestan, por citar ejemplos ilustrativos, las monedas episcopales de Vic y Girona ${ }^{3}$.

La circulación más temprana de mancusos de oro también consta en los territorios catalanes, pues se documentan ya en el 978, si bien se trataba de piezas musulmanas, en concreto de Yafar, primer ministro de al-Hakam II, califa de Córdoba ${ }^{4}$. La aparición de esta moneda foránea, que contó con una intensa circulación aunque limitada a nivel geográfico ${ }^{5}$, se debió a las expediciones de mercenarios catalanes al mundo andalusí y, posteriormente, a las parias o tributos que las taifas debían pagar a los condados cristianos. Parece ser que el descenso en la recepción de esta moneda procedente de territorio musulmán provocó la rápida acuñación de oro en Barcelona ${ }^{6}$, por lo que los condes decidieron emitir sus propios mancusos según el modelo musulmán evidenciando uno de los caracteres más sugerentes del mundo peninsular medieval: el orientalismo, que tiene en la numismática una de sus más claras manifestaciones ${ }^{7}$.

Si los primeros ejemplares copiaron los tipos musulmanes, muy pronto la autoridad emisora introdujo nuevos elementos con el fin de identificarlos como propios. En el caso barcelonés llama la atención el batido por Ramón Berenguer I (1035-1076), llamado bilingüe, por mostrar inscrita en una de sus caras la leyenda RAIMVNDVS COMES en caracteres latinos. Con ella, el conde acuñaba por vez primera una moneda de oro, material tradicionalmente reservado a la máxima soberanía ${ }^{8}$, con su nombre inscrito en su superficie. De acuerdo con Balaguer, esta medida respondía a una voluntad de erradicar los talleres difusores de la moneda áurea, en concreto los de carácter privado ${ }^{9} \mathrm{y}$,

\footnotetext{
${ }^{3}$ Adornados con detallados bustos de Cristo, de la Virgen o de los santos. Sus composiciones remiten a fórmulas de procedencia bizantina. Sobre ellas, Balaguer 1999.

${ }^{4}$ Balaguer 1984, p. 314.

${ }^{5}$ Reglà supuso que los territorios catalanes funcionaron como bisagra en la circulación de mancusos musulmanes hacia zonas ultrapirenaicas: Reglà 1969, p. 209. No obstante, Balaguer explica que este tipo apenas superó los condados catalanes, pues sólo advierte breve circulación áurea en el Languedoc, cuando Ramón Berenguer I adquirió Carcasona y Rasés: Balaguer 1999 , p. 70.

${ }^{6}$ Balaguer 1999, pp. 70-72, desarrolla esta cuestión.

${ }^{7}$ Entre otros, Lavoix 1891; Botet 1908-1911; Crusafont 1982.

${ }^{8}$ Material distinguido también en la cultura oriental. En la península fue Abderramán III (912-961) quien, tras intitularse Imam y Príncipe de los Creyentes, procedió a emitir moneda áurea. Con esta iniciativa rompía con la tradición de sus predecesores, quienes no osaron hacerlo por constituir un atributo de suprema soberanía que sólo podía asumir el Califa de Oriente, único representante del Profeta. Sobre esta amonedación, Rivero 1955, p. 53. Sobre la presencia de nombres y títulos califales en Al-Andalus como expresión de la articulación del poder en la moneda, Canto 1998, p. 111.

${ }^{9}$ Como los de Bonhom y los de Eneas. Un documento de 1069 parece confirmarlo según Balaguer 1999, p. 318.
} 
por tanto, se debía a un deseo de revalorización de la suya propia. Esta hipótesis, contrastada documentalmente ${ }^{10}$, no desautoriza la que décadas antes proponía Lluís y Navas-Brusi en relación con el defecto de índole jurídica y ética que pudo haber al utilizar los símbolos de otro poder público sin la autorización de este y sobre el cual carecía el conde de autoridad ${ }^{11}$, así como tampoco se desdeñará el conflicto que se inició con el papado, que censuraba estas emisiones con inscripciones infieles por parte de las autoridades cristianas ${ }^{12}$.

Es probable que esta reprobación fuese la que llevó a acuñar mancusos excepcionales. Dejando a un lado las monedas bilingües y los singulares aunque tardíos maravedíes de Alfonso VIII (1158-1214) ${ }^{13}$, resultan ilustrativos los mancusos emitidos en oro y en una fecha supuestamente cercana a 1089 por Sancho Ramírez (1064-1094) ${ }^{14}$.
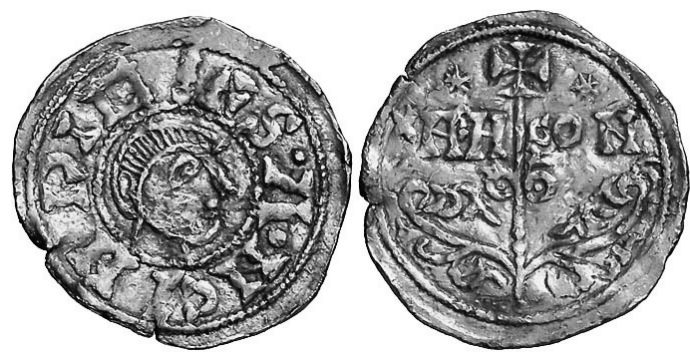

Fig. 1. Mancuso de Sancho Ramírez (atribuido), Mancusos Iacensis o auro de Iacca. Anverso y reverso.

Se ha pensado si esta acuñación, que aparece en la documentación como mancusos Iacensis o auro de Iacca, sería consecuencia de la infeudación a la Santa Sede protagonizada por este monarca durante su viaje a Roma en 1068 y que implicaba el pago al Santo Padre de 500 mancusos anuales. De

\footnotetext{
${ }^{10}$ Ibidem, doc. 12 del ap. doc.

${ }^{11}$ Lluís 1956, pp. 41-42.

${ }^{12}$ Ibidem.

${ }^{13}$ Donde con grafía árabe se indicaba "El iman de la Iglesia del Mesías es el papa romano ALF". Todo rodeado por "En nombre del Padre, y del Hijo, y del Espíritu Santo, Dios es único. El que cree y que ha sido bautizado será salvado". En el reverso, "El emir de los católicos Alfons ben Sanch está ayudado de Dios y Dios le protege". Todo rodeado por "Este dinar ha sido acuñado en Medina Toleitola, el año 1225 de la era de Saphar”: Heiss 1867, vol. I, pp. 28-29, lám. 4. Sobre estos morabetinos, es ilustrativo Francisco 1998, pp. 283-301.

${ }^{14}$ Amonedación que no reflejaron los catálogos de Heiss 1867, vol. II, pp. 3-4, lám. 71 o de Gil 1974, pp. 260-261. Sí se incluye en otros, como Crusafont 1992, p. 49.
} 
ella lo primero que sorprende es su tipología pues, prescindiendo del modelo musulmán, exhibe la iconografía que es propia de sus otras acuñaciones jaquesas; esto es, en el anverso busto de perfil rodeado por +S.A.NC IN D NE, y cruz en el reverso circundada por el término ARA-GON ${ }^{15}$. Que los pocos ejemplares encontrados se hayan localizado en el Mediterráneo oriental ${ }^{16}$ ha llevado a suponer si fueron utilizados por el Pontífice para costear la Primera Cruzada, por lo que cabría presumir que Sancho Ramírez concibió una nueva moneda áurea destinada, en exclusiva y consciente de la expansión geográfica que ésta podría tener, a satisfacer la infeudación. Si dejamos al margen la supuesta falsedad de la acuñación, sobre la que ya se pronunció Gil Farrés ${ }^{17}$ aunque sin consenso, lo que más llama la atención de la misma es, en oposición a este tipo de numerario que ya era frecuente en el resto de territorios cristianos peninsulares y que seguía los patrones musulmanes, la utilización de una iconografía particular, acaso en respuesta a la amonestación papal, y que suponía, tanto por la imagen como por la leyenda en ella estampadas, una evidente manifestación regia.

\section{SANCHO RAMÍREZ Y LAS PRIMERAS EMISIONES DE VELLÓN}

Hace algún tiempo que la historiografía acepta, salvo escasas excepciones ${ }^{18}$, que las primeras amonedaciones en Aragón emergieron durante el reinado de Sancho Ramírez. Es sintomático que surgieran poco después de que alcanzase, en 1076, el trono pamplonés pues, con este derecho, se disipaba cualquier duda con respecto a su condición regia: que Sancho Ramírez utilizase por vez primera el término rex en su documentación a partir de la incorporación del reino de Pamplona tras la muerte de Sancho IV es ilustrativo ${ }^{19}$

${ }^{15}$ Leído como "Sancius in Dei nomine" o "Sancii nostri mancusus": Royo 2008; Lapeña 2004, p. 112; Beltrán 1972b, vol. II, p. 490; o Beltrán 1972, p. 163.

${ }^{16}$ Turquía y Siria, concretamente.

${ }^{17}$ A instancias del conservador del Museo Arqueológico Nacional examinó la pieza y concluyó que "ce mancuso est un faux", cita Ibáñez 1998, p. 80, n. 3, quien también duda de su autenticidad, aunque desconozco sus argumentos.

${ }^{18}$ Que sostienen que un dinero de vellón, con busto de perfil a la izquierda rodeado por IMPERATOR en el anverso y el denominado árbol superado en cruz con NAVARA, según algunas lecturas, horizontalmente a los lados en el reverso, como propio de Sancho III el Mayor. Entre ellos, Heiss 1867, vol. III, pp. 11-13, lám. 144; Sánchez Albornoz 1928, pp. 1-46; Menéndez Pidal 1969; De Iruña 1935, pp. 655-660; Beltrán 1972a, pp. 51-112; Amorós 1954, pp. 17-40; Crusafont 1992. Entre quienes lo descartan, Gil 1955, pp. 43 y ss., pronto seguido por Ibáñez, quien niega esta atribución al tiempo que realiza un estado de la cuestión en Ibáñez 1993, pp. 110-118. Lo atribuye a García IV de Navarra en Ibáñez 1993-1994, pp. 141-197. 1991.

${ }^{19}$ Se intitulará como "Sancius, gratia Dei rex Aragonensium et Pampilonensium": Ubieto 
pues supone, junto con otros mecanismos ya analizados por Laliena ${ }^{20}$, un claro robustecimiento del poder real.

No hay duda de que uno de los elementos que más contribuyeron a esta reafirmación fue la emisión de moneda propia que, además de su función social y económica, tuvo también un importante papel propagandístico ${ }^{21}$.
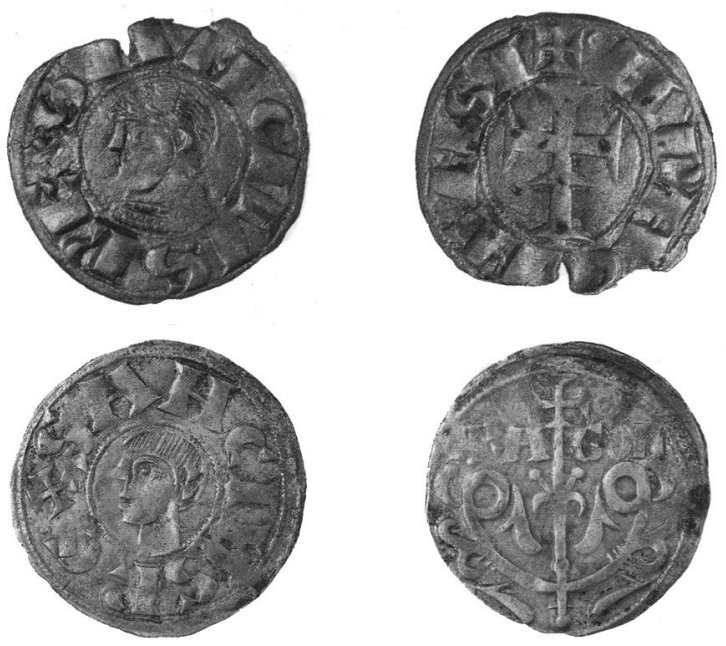

Fig. 2. Emisiones de Sancho Ramírez, con diversidad de leyendas: Aragonensi, Iacca... Anversos y reversos.

Y es ahí donde entra el papel de la iconografía: esta moneda, de la que se han conservado numerosas variantes en valor y detalles que confirman la intensa actividad numismática del momento ${ }^{22}$, presenta el busto del monarca en el anverso y una cruz en el reverso, tipo compositivo que se mantendrá, con pocas modificaciones, hasta Sancho el Sabio (1150-1194) ${ }^{23}$, conformándose como la más característica de este siglo en el territorio navarro-aragonés.

\footnotetext{
${ }^{20}$ Laliena 1996.

${ }^{21}$ Ibáñez 1998, p. 80. Para este argumento resultan ilustrativos "El monarca i els atributs del seu poder. La imago regis" o "El nom del sobirà" en Campo 1998, pp. 18-19 y 22-23.

${ }^{22}$ Sobre la "explosión monetaria" que supusieron las emisiones de Sancho Ramírez, sus devaluaciones y falsificaciones acaso acuñadas en talleres oficiales, Ibáñez 1998.

${ }^{23}$ En Aragón proseguirán con su acuñación Pedro I (1094-1104) y Alfonso I (1104-1134), mientras que en Navarra lo harán García IV (1134-1150) y Sancho el Sabio (1150-1194).
} 


\subsection{Las particularidades del anverso: el busto de perfil}

Los precedentes de este tipo monetario, donde la autoridad emisora figura en perfil, pueden encontrarse en la Península, en concreto en los problemáticos diners del conde barcelonés Berenguer Ramón I (1018-1035).
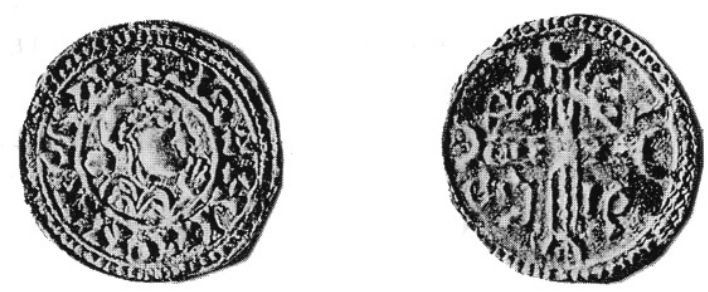

Fig. 3. Dinero de Berenguer Ramón I (1018-1035) (atribuida). Anverso y reverso.

En ellos puede verse, en su anverso, un busto a la izquierda o derecha según los casos, cuya naturaleza (si es civil o eclesiástica) no ha podido ser aún hoy reconocida: que muestre las manos en actitud de bendecir ha llevado a suponer que se trataría de un obispo, hipótesis que se vería refrendada si la lectura de la leyenda que lo circunda aludiese a Deodato, obispo de Barcelona durante el arco cronológico en el que Berenguer Ramón I ejerció el poder ${ }^{24}$. Esta propuesta, que supone el busto como perteneciente a un prelado, no resulta del todo satisfactoria al no constar monedas emitidas por obispos en este mismo momento cuyas efigies no ostenten uno de sus atributos más característicos: el báculo ${ }^{25}$, insignia aquí ausente. No obstante, y aunque es llamativo que no todas las variantes muestren este gesto particular ${ }^{26}$, en favor de esta hipótesis se recordarán como precedentes, tempranas aunque elocuentes, algunas emisiones francas del siglo VII: quizás una de las más cercanas sea la del obispo de Puy, quien se hacía representar con un busto rudimentario en perfil, sin mostrar ninguna insignia

${ }^{24}$ Balaguer y Crusafont leyeron la grafía como -B-Co-D-E-, B[erengarius] Co[mes] $\mathrm{D}$ [eodatus] $\mathrm{E}$ [piscopus], lo que les permitía identificar coherentemente al personaje, aunque no lo afirmaban con rotundidad: implicaba la lectura de una extraña D cursiva, Balaguer, Crusafont 1983 , p. 67.

${ }^{25}$ Las emisiones episcopales de los condados catalanes ofrecen amplia variedad de tipos, aunque en ningún caso se asemejan a la pieza aquí abordada. Habrá que esperar a principios del s. XII para encontrar una moneda con una figura de medio cuerpo que, ataviada con capa pluvial y báculo, bendiga con la derecha. Es una emisión de Vic catalogada en Balaguer 1999, tip. 46, p. 417.

${ }^{26}$ Así, el único signo episcopal desaparece en algunos casos. Ibidem, pp. 371-393. 
y acompañado de una mano bendiciendo, pronunciando, conforme a Engel y Serrure $^{27}$, el pax vobis, fórmula de salutación exclusiva del obispo. Una segunda propuesta de lectura de las letras entalladas de la acuñación barcelonesa, y que abogaría por una alusión a Berenguer ${ }^{28}$, interpretaría el busto como la efigie del conde barcelonés a pesar del gesto bendicente, si bien hay autores que sostienen que, en este segundo supuesto, podría mantenerse también la identificación con el eclesiástico, por lo que la iconografía evidenciaría los privilegios que los obispos tenían sobre la moneda barcelonesa ${ }^{29}$.

Si se concluye que el busto de la moneda barcelonesa representa a un mitrado, será necesario dirigir la mirada a territorio ultrapirenaico para encontrar un precedente para la amonedación de Sancho Ramírez. Estos antecedentes se localizarían en las emisiones alemanas del siglo X y principios del XI, a su vez inspiradas en las inglesas de la segunda mitad de la décima centuria ${ }^{30}$. Una mirada rápida por el repertorio numismático de este período explicita la riqueza tipológica de las emisiones germanas en contraposición a las francas, acaso como resultado de sus divergentes situaciones políticas ${ }^{31}$.
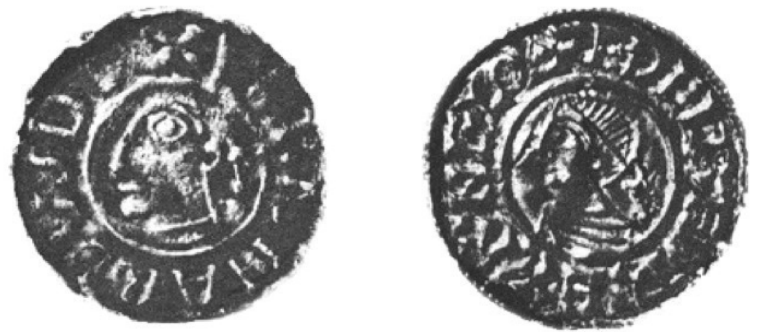

Fig. 4. a) Dinero de Bernardo I, duque de Sajonia. Finales del siglo X o inicios del XI.

b) Emisión de Atalredo II de Inglaterra. Finales del siglo X o inicios del XI.

${ }^{27}$ Su leyenda parece rezar G......IIVS EBESCOBUS. Los autores, al constatar tipos análogos en Brioude, Tolouse y en otras zonas emitidos por la autoridad eclesiástica, concluyeron que la efigie debía de representar a un obispo: Engel, Serrure 1890, vol. I, figs. 245-246, p. 160.

${ }^{28}$ Calicó 1982,p. 32; Balaguer, Crusafont 1983, p. 67.

${ }^{29}$ También recuerdan la existencia de una moneda acuñada en Arlés, de tiempos de Alfonso II, donde se observa una mitra que refleja, como en este caso, la participación episcopal en la emisión: ibidem, p. 68.

${ }^{30}$ En este momento el sistema monetario británico era uniforme en tipos y pesos, lo que ha llevado a calificarlo como nacional: Grierson 1976a, p. 94.

${ }^{31}$ La monarquía francesa no era fuerte, por lo que la moneda, reflejo de realidades políticas, fue fundamentalmente epígrafe o con algún monograma, si bien existen algunos tipos figurativos de primitivo diseño. Alemania, pujante, con profusión de talleres y con dos grandes poderes (iglesia y emperador) fue cuna de ricas iconografías. Ibidem, pp. 86-87. 
Ejemplo de estas analogías lo brinda un dinero de Bernardo I (9731011), duque de Sajonia, familia emparentada con numerosas casas regias europeas, que presenta la cabeza del soberano a la izquierda rodeado de su título: el parecido con la moneda del aragonés es evidente. Dos de las diferencias de estas acuñaciones con las que se emiten, en el mismo período, en Inglaterra, son la profusión de tipos con bustos colocados de frente ${ }^{32} \mathrm{y}$, ya en el caso de los bustos de perfil, la ausencia de insignias regias, como pone de manifiesto una de las emitidas por Etelredo II (979-1016).

No resulta extraño, pues, el uso de figuración regia en pleno siglo XI, momento en el que algunas autoridades, laicas y eclesiásticas, promovieron su representación plástica en uno de los campos de sus amonedaciones. Descartando cualquier tipo de intención retratística, pues nunca pretendieron estampar su vera imago ${ }^{33}$, su intencionalidad fue la de plasmar la regia dignitas del titular. Es cierto que la efigie de Sancho Ramírez carecía de cualquier insignia que denotase el grado de auctoritas, pero no hay que olvidar que aquella, siempre, se rodeaba por SANCIVS REX ${ }^{34}$, por lo que su dignidad quedaba enunciada y, inequívocamente, expresada. También debe valorarse la creación de moneda como tal, batida en un momento en el que la reanimación demográfica y la expansión económica obligaban a una mejor adecuación de los instrumentos de cambio. No cabe duda de que, al no ser suficientes las especies monetarias que entonces circulaban, procedentes de territorio andalusí, el rey de Aragón y de Pamplona decidió emitir, por vez primera, su propia moneda. Tal y como recordaba Ramírez, al soberano aragonés le interesaba demostrar sus poderes fácticos, uno de cuyos baluartes era la emisión de moneda: la facultad de efectuar pagos con piezas propias; suyas, apostillaría la autora $^{35}$.

Bajo la elección del busto del monarca para el anverso de sus acuñaciones se escondía una intencionalidad política. La más evidente, y que subya-

\footnotetext{
${ }^{32}$ Invaden la franja destinada a la leyenda y son muy cuidadas en detalles de la indumentaria e insignias.

${ }^{33}$ Unánimemente se considera que el inicio de las acuñaciones con retratos reales se produjo con los macedonios Demetrios (292 a. C) y Antígono (227 a. C), práctica que en Roma llegó a su culmen con ejemplares como los de Cayo Julio César (45 a. C). Los poderes fácticos de la Edad Media, salvo unas monedas de Conrado II (990-1039) de las que Grierson afirmó que "la tête barbue (...) correspond à la description qu'en donnent les sources littéraires", no se interesaron en esta fidelidad fisonómica: Grierson 1976a, p. 86. En la Península, aunque Babelon consideraba que no los hubo antes de 1450, las amonedaciones del rey Martín I (1396-1410) parecen demostrar un efímero cambio: Babelon 1953, p. 68.

${ }^{34}$ SANCIVS REX / ARAGONENSI; SANCIVS REX / IACCA; SANCIVS REX / MONSON; SAN.CIVSRES/ ARA-GON; SANCIVS REX/ ARA-GON; etc. Entre otros, Ibáñez 1993-1994; Jusué, Ramírez 2002.

${ }^{35}$ Ramírez 1996, p. 162.
} 
ce bajo esta imitatio compositiva, la de mostrar y evidenciar que se integraba dentro del distinguido y poderoso círculo que, por entonces y en el entorno europeo más o menos próximo, ostentaba la autoridad. Pero por otro lado, la confirmación de la autoridad real puesta en entredicho por los reinos vecinos, en concreto el castellano ${ }^{36}$, argumento, sobre el que volveremos.

Un rápido cotejo entre estas monedas aragonesas y las de los condados catalanes y, a partir de $1085^{37}$, las del reino castellano lleva a fructíferas conclusiones. Entre ellas, y al margen del estímulo primigenio, pues en todos los territorios se acuñó para sustituir la moneda hispanomusulmana y satisfacer las necesidades de la incipiente burguesía, destaca la similitud con respecto a los patrones carolingios; la elección de los dineros como tipo preferido y, por tanto, de vellón; y también la acuñación de grandes cantidades de numerario, en general de buena ley. Las mayores diferencias son de carácter iconográfico: la asimilación de la efigie del poder emisor, entonces inmerso en luchas internas que le obligaban a reafirmar y sancionar su posición preeminente, tuvo el propósito de reflejar, plásticamente, su auctoritas ante los súbditos.
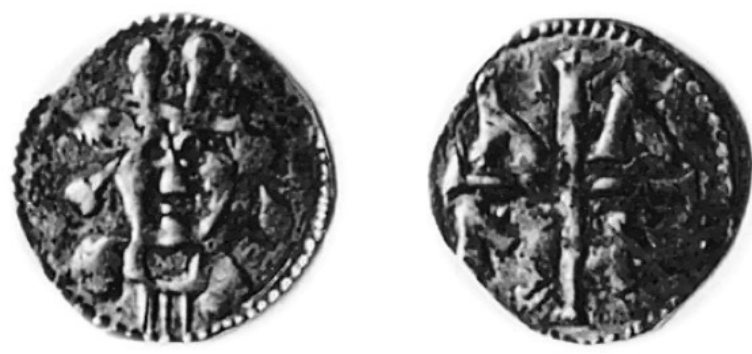

Fig. 5. Dinero de Ramón Berenguer I (1035-1076), de la ceca de Gerona. Anverso y reverso.

En esta línea explicativa pueden resultar ilustrativos los diners de Ramón Berenguer I (1035-1076) originarios en la ceca de Girona ${ }^{38}$, pues son los primeros ejemplares cristianos peninsulares en presentar la efigie frontal

\footnotetext{
${ }^{36}$ Parafraseando a Ibáñez 1998, p. 80.

${ }^{37} \mathrm{Se}$ considera que en Castilla las acuñaciones se inauguraron con Alfonso VI tras conquistar Toledo.

${ }^{38}$ Acuñó también òbols con esta tipología. La amonedación plenamente condal en Girona se inició con este conde y concluyó con Alfonso II. Con Ramón Berenguer III, en este mismo territorio, cesaron las monedas episcopales o semiepiscopales: Balaguer 1999, pp. 150-152.
} 
del poder emisor desde los visigodos ${ }^{39}$. Bajo esta extraordinaria acuñación, que rompe con las tradicionales iconografías autóctonas de bustos en perfil de santos, pero que al tiempo, y quizás no sea casual, enlaza por sus similitudes compositivas con las que efigiaban a Cristo y a la Virgen María, también frontales, subyace una voluntad de ostentación de poder. Se había creído que la donación en 934 del tercio del beneficio de la moneda batida en el condado de Girona a la iglesia de Santa María por parte del conde Sunyer supuso para éste, y como consecuencia también para sus descendientes, la pérdida o la renuncia del control monetario en ese territorio. Es cierto que algunas evidencias documentales, ya de tiempos del propio Sunyer $^{40}$, parecen demostrar que los condes, no obstante, se sintieron poseedores de este derecho; sin embargo, pese a ser conscientes de su prerrogativa para batir moneda, sólo hicieron uso de ella a partir de Ramón Berenguer I, quien se vio obligado, por el férreo carácter de Ermessenda, que se negaba a cederle el gobierno tras alcanzar la mayoría de edad, a comprar sus derechos en Girona, entre otros el de amonedar ${ }^{41}$. No parece casual que, recuperado el privilegio de acuñación de moneda, una de las más importantes preocupaciones de Ramón Berenguer I en territorio gerundense, el conde escogiera la tipología de busto de frente, hasta entonces reservada a las efigies de Cristo y de la Virgen María de innegable origen visigodo y bizantino ${ }^{42}$.

Idénticas raíces imperiales tenían las acuñaciones que, con esta tipología de frente, se abrían en el continente europeo, cada vez más prolijo en el terreno iconográfico. Como advirtieron Engel y Serrure, el tipo de cabeza imperial o real de frente, que Dannenberg creía introducida en Alemania desde

\footnotetext{
${ }^{39}$ Esta moneda fue catalogada por Botet i Sisó como perteneciente a Ramón Berenguer III, y por Crusafont como de Ramón Berenguer IV: Crusafont 1982, p. 61. En un catálogo posterior incorpora una de sus variantes a nombre de Ramón Berenguer I: Crusafont 1992, p. 28. Su anverso exhibe el busto del conde mirando al frente nimbado por corona de altos remates terminados en perlas y de cuyos lados penden lambrequines. En su reverso, como es tradicional en el numerario de los condes catalanes, una cruz, aquí patada y cantonada por R-A-M-N.

${ }^{40}$ Aunque también de Ramón Berenguer I y Ramón Berenguer III. Documentos transcritos en Balaguer 1999, pp. 338-340.

${ }^{41}$ Custodiada por su hermano, el obispo Pere de Girona, y por el obispo de Vic, Ermessenda, viuda de Ramón Borrell, ejerció el poder durante la minoridad de su nieto. Así, Ramón Berenguer I, hacia 1309-1041, sólo gobernaba sobre el Vallès y Barcelona. Tras un primer acercamiento, en 1057 se establecía un acuerdo por el que la condesa vendía, por mil libras de oro, todos sus derechos en los condados y obispados de Barcelona, Girona y Osona-Manresa, y en los castillos de Begur, Pierola, Pontils y Cardona. Prestó homenaje al conde y a su esposa Almodis y se comprometió a gestionar el alzamiento de las excomuniones que, sobre ellos, había instigado: entre otros, Salrach 1987, vol. I, pp. 167 y ss.

${ }^{42}$ Leovigildo, quien introdujo circulante autónomo en la Península visigoda, acuñó con su nombre suprimiendo el del emperador de Oriente. Batió tres tipos de trientes: Gil 1974,pp.73-74. Marot insistía en su influencia bizantina: Marot 1997, pp. 259-260.
} 
Otón I, denunciaba un innegable origen bizantino ${ }^{43}$. Principalmente utilizada en la cuenca del Rhin, pasó desde Estrasburgo hasta Utrecht para seguir hacia los Países Bajos y luego a Inglaterra, lugar donde se convirtió, con Guillermo II (1087-1100) y sus sucesores, en la marca habitual de los pennies ${ }^{44}$. Fue pues a partir de la zona oriental de Alemania, en el centro de Goslar ${ }^{45}$, donde existía una importante ceca fundada por Enrique III (1046-1056) ${ }^{46}$, desde donde se exportó con prontitud la influencia bizantina por todo el continente, sin constituir el condado barcelonés una excepción.

Dejando al margen el tipo de tocado que presenta el conde de Barcelona en esta nueva amonedación ${ }^{47}$ cuya novedosa iconografía plasma su auctoritas sobre un territorio donde había tenido que imponerse, hay que desplazarse a territorio leonés y castellano para ver otro ejemplo que ilustre la utilización de una nueva iconografía numismática como herramienta de prestigio: me refiero a unas insólitas acuñaciones de Alfonso VI (10731109) descubiertas en 2003. Sabido es que este rey acuñó por vez primera moneda propia tras la conquista de Toledo siguiendo dos tipologías: la islámica y la llamada "de estrellas y roeles" 48 . No obstante, hace menos de una década Hernández-Canut sacaba a la luz tres piezas singulares que, de entre 1085 y 1088, exponen la efigie de frente del soberano ${ }^{49}$. Conforme a su hipótesis, el rey Alfonso incorporaba a su repertorio numismático el busto de frente como una muestra más del neogoticismo del que hacían gala los reyes de León y Castilla y que también se revelaba a través de otras vías, como el uso de la letra visigoda en las cancillerías, la continuidad de la liturgia hispanovisigoda o la pervivencia de la legislación del Liber Iudiciorum ${ }^{50}$. Acaso habría que ver en estas ansias por entroncar con los visigodos un recurso

${ }^{43}$ Aunque en Persia Artabanus (213-277) acuñó con busto real de frente o en perfil: Gil 1974,p. 42.

${ }^{44}$ Más detalles sobre la dispersión de esta tipología en Engel, Serrure 1890, vol. II, p. 530.

${ }^{45}$ Cuyos temas más característicos fueron el busto de frente y los de Simón y Judas: Gil 1974, p. 105.

${ }^{46} \mathrm{El}$ taller fue creado para convertir en especie los lingotes de plata que se extraían de las minas de Hartz, centro de la influencia artística bizantina: Engel, Serrure 1890, vol. II, p. 530

${ }^{47}$ Es conocida la abundancia de ornamentación en las diademas que ceñían los bustos de la numismática clásica, donde el laurel declinó su protagonismo ante nuevos elementos de perlas y pedrería: los sólidos de Constantino el Grande son un ejemplo. Más cercanas geográficamente son las monedas de la Tarraco de Augusto, donde el emperador ciñe diadema irradiada y atada mediante nudo en la nuca, expresando su divinización. Ejemplos en Villaronga 1987, figs. 1047, 1049, 1054 y 1060. Esta ornamentación se repitió en la numismática medieval: lo ilustran los pennies de Edgard I de Inglaterra (959-975), quien se representa con corona ceñida mediante lazo a partir del que cuelgan lambrequines (Brooke 1950, lám. XVI, fig. 1), y la moneda condal que aquí se trata.

${ }^{48}$ Véanse Heiss 1867; Gil 1974; Álvarez 1998.

${ }^{49}$ Hernández-Canut 2005, pp. 1199-1203.

${ }^{50}$ Ibidem, p. 1200. 
legitimador, como han expuesto varios autores ${ }^{51}$, pero también una manifestación de confrontación con respecto al rey de Aragón, con quien mantuvo serios conflictos y cuya política fue, como luego se recordará, tan divergente. En este sentido puede ser clarificador que, en el reino de León, durante el dificultoso gobierno conjunto de doña Urraca, hija de Alfonso VI, y de su esposo Alfonso I de Aragón (1109-1126), quien la repudiaría en 1114, la reina escogiera idénticos tipos a los de su padre y, en cambio, don Alfonso no emitiera con este tipo particular que remitía, en última instancia, a las acuñaciones de Witiza, el último rey visigodo ${ }^{52}$.

Así, puede afirmarse que la elección de nueva iconografía en la numismática respondió a una voluntad propagandística, por lo que hay que buscar en la incorporación de nuevos modelos figurativos una finalidad, del carácter que sea, por parte del poder emisor. Como queda dicho, para sus nuevas monedas Sancho Ramírez escogió un modelo ya conocido en el ámbito ultrapirenaico, decisión que no resulta extraña en un monarca del que se ha destacado su papel europeísta ${ }^{53}$ : sus vínculos con Roma, la presencia de milicias extranjeras en su reino para colaborar en sus conquistas (aunque no siempre con el beneplácito del soberano), la llegada e instalación de francos en su territorio, o la promoción del peregrinaje a Santiago, son algunos de los ejemplos que se pueden enumerar.

Dentro de su estrategia política que repercutía en todos los ámbitos, incluso artísticos, Jaca tuvo un papel preponderante: si no capital ${ }^{54}$, convertida en sede o en ciudad preeminente acaso como imitación de algunas ciudades visitadas por el rey en su viaje a Roma ${ }^{55}$, asumió un nuevo rango a nivel político, económico y religioso hacia 1077. Receptora de un fuero especial, adquirió nueva categoría y, con consecuencias urbanísticas ${ }^{56}$, se convirtió en un lugar privilegiado con edificios de envergadura, entre otros la catedral de San Pedro.

${ }^{51}$ Sobre el argumento goticista y sus problemas historiográficos, Isla 2011, pp. 11-21.

${ }^{52}$ En concreto de Witiza: Hernández-Canut 2005, pp. 1199-1203.

${ }^{53}$ Entre los trabajos que giran en torno a este argumento, son fundamentales los estudios de Buesa, Durán, Kehr, Lacarra, Laliena, Martín Duque, Sarasa y Ubieto.

${ }^{54} \mathrm{La}$ ausencia de una importante administración y que el rey no residiera de forma constante en Jaca llevó a descartar que pudiera definirse la ciudad como capital a Laliena, Sénac 1991, p. 133. Pero Sancho Ramírez proclamó el cambio jerárquico de Jaca: "Esta es una carta de autoridad y confirmación por la cual yo, Sancho, por la gracia de Dios rey de los aragoneses y de los pamploneses, os hago saber a todos vosotros, todos los hombres que están en oriente y occidente, septentrión y mediodía, que yo quiero fundar una ciudad en mi villa que llamada Jaca”: Falcón 1994, pp. 122-124.

${ }^{55}$ Conforme a Sesma 2003, p. 204.

${ }^{56}$ Sobre ello, Betrán 1999; Betrán 1992; Bielza 2003, pp. 267-316. 

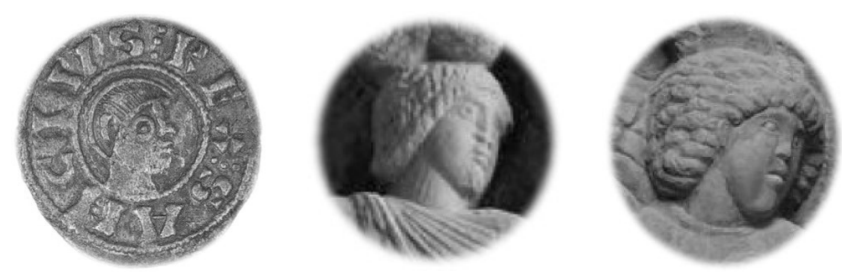

Fig. 6. a) Emisión de Sancho Ramírez atribuida al llamado Maestro de Jaca.

b) y c) Detalles de los rostros esculpidos por este maestro en la catedral jacetana.

Allí acudieron una serie de maestros que dejaron impronta de su habilidad en el plan arquitectónico, la estereotomía y la decoración cincelada de sus capiteles, y en su versatilidad: de acuerdo con Moralejo ${ }^{57}$, el llamado "maestro de Jaca" habría sido el artífice de uno de los cuños monetarios de Sancho Ramírez, pues en uno de sus tipos observa unos rasgos faciales que, en contraste con las formas angulosas del resto de monedas (con lacrimal marcado, potente mentón y una geométrica forma de resolver el tabique nasal), presenta unos ritmos curvos que, según la escultura que talló en la catedral, son los habituales en los tipos faciales de este maestro.
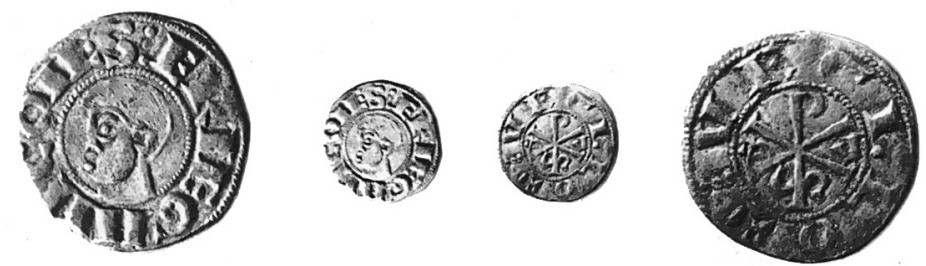

Fig. 7. Moneda del conde de Urgell Ermengol IV (1065-1092). Anverso y reverso.

Me pregunto si este maestro sería también quien cincelaría, o habría cincelado ya, los cuños del conde de Urgell Ermengol IV (1065-1092), quien gobernó a los doce años bajo la tutela de la condesa Sancha de Aragón, hermana de Sancho Ramírez y tan vinculada al rey en los asuntos de gobierno. Más adelante retomaré la cuestión.

\footnotetext{
${ }^{57}$ Moralejo 1984, pp. 29-35.
} 


\subsection{Las particularidades del reverso: la cruz sobre vástago}

Por otra parte, las emisiones de Sancho Ramírez despliegan unos reversos también particulares. Generalizando, puede afirmarse que sus campos presentan cruces, motivo religioso común que, como reverberación constantiniana según la tradición ${ }^{58}$, hay que asociar a la dignidad regia ${ }^{59}$. Recordaba Grierson que fue Tiberio II Constantino (578-582) quien instauró en sus reversos el tipo de cruz sobre gradas ${ }^{60}$, tipo de cruz que, como reacción contra las monedas de Justino ${ }^{61}$, rememoraría una visión que habría tenido este emperador y que tendría la capacidad de perpetuar en el recuerdo la gran cruz enjoyada que aquel erigió en la iglesia del Santo Sepulcro de Jerusalén ${ }^{62}$. Sea como fuese, este tipo de reverso fue imitado casi al mismo tiempo por Leovigildo entre 578 y 584, y continuó empleándose, con variantes, durante siglos, por lo que este reverso crucífero fue conocido coetáneamente en suelo peninsular.

No cabe duda de que el reverso crucífero de las primeras amonedaciones de Sancho Ramírez no puede asociarse a las denominadas à la croix ya que superficialmente, aunque presentan idénticas características en anverso y reverso, esto es, busto/cruz, poco comparten con respecto a su significado ${ }^{63}$. Estas monedas crucíferas, que arrancan en el mundo griego y que, como derivación de la cruz constantiniana, se generalizarán por el continente europeo, son las que, ya en la segunda mitad del siglo XII, derivarán en los croats después de la unión del reino de Aragón con el condado de Barcelona, tipo numismático que, por otra parte, ultrapasará el reinado de los Reyes Católicos.

\footnotetext{
${ }^{58}$ La atribución a Constantino del origen victorioso de la cruz no responde a la realidad. Detalles y bibliografía en García de Castro 2009, pp. 379 y ss.

${ }^{59}$ Menéndez Pidal 1955, citado en Montaner 1995, p. 20. "En mitad del día, el sol comienza a declinar, él ha visto por sus propios ojos el signo de la cruz brillando luminosamente en medio del cielo más aún que el sol, con estas palabras: con esta vencerás": Eusebio de Cesarea 1994, cap. 28.

${ }^{60}$ Aunque Próspero de Aquitania había atribuido su introducción en tiempos de Arcadio, quien habría colocado una cruz en sus emisiones para celebrar su victoria contra los persas tras aparecer, milagrosamente, cruces sobre las ropas de sus soldados: Grierson 1976 b, p. 615.

${ }^{61}$ Con la personificación de Constantinopolis entronizada: ibidem, p. 616.

${ }^{62}$ Ibidem.

${ }^{63}$ Son las monedas de a partir de finales del siglo III hasta el I a. C y halladas en diversas áreas como Suiza, Norte de Cataluña, Sudeste de Francia, o Europa Central. Las han estudiado, Jean Claude-Michel Richard, Jean-Baptiste Colbert de Beaulieu o George Savès.
} 
Por contra, las cruces que campean en los reversos ramirenses tienen unas particularidades iconográficas que, a mi entender, tienen poco que ver con estas figuras à la croix mencionadas, y, como argumentaré, tienen una trascendencia simbólica sólo explicable en relación con la personalidad del monarca que las promociona.
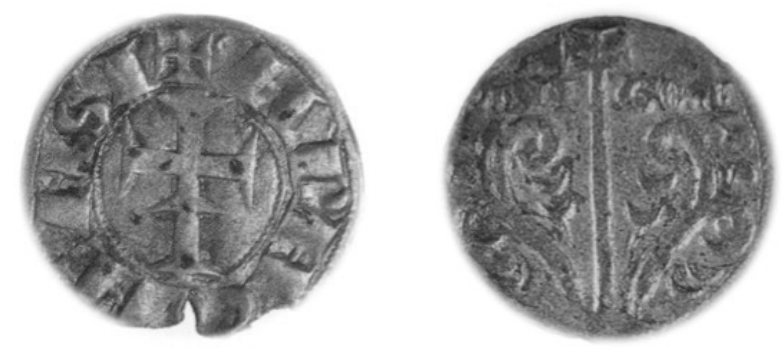

Fig. 8. Emisiones de Sancho Ramírez. Tipologías de reversos.

De los dos tipos de reversos utilizados por Sancho Ramírez me centraré, primero, en el que la historiografía ha presentado mayores dudas, por lo que voy a prescindir, de momento, de la "cruz procesional" para focalizar la atención en el elemento definido como "árbol superado en cruz", "árbol de Sobrarbe" o "árbol crucífero de Sobrarbe" ${ }^{64}$. Fueron muchos quienes, desde 1499 y encabezados por de Vagad, supusieron que esta insignia era una alusión al emblema parlante originado durante la toma de Aínsa ${ }^{65}$, aunque pronto hubo quienes descartaron esta posibilidad: el árbol de Sobrarbe es una simple y nueva invención, aseguraría de Zurita sin vacilación ${ }^{66}$. Por otra parte, y si estamos de acuerdo con Menéndez Pidal ${ }^{67}$, en la estela de Domènech i Montaner y Domènech i Roura ${ }^{68}$, esta figura sería una forma de lábaro o de cruz procesional en la que los aparentes ramajes serían ornamentaciones que, con el tiempo, se habrían asimilado a la encina crucífera, por lo que cabría sospechar, o mejor concluir, que esta cruz ornamentada no tuvo ningún tipo de significación emblemática, al menos, en origen.

\footnotetext{
${ }^{64}$ Montaner 1995, pp. 16-22.

${ }^{65}$ Según la leyenda, García Jiménez fue sorprendido por los musulmanes, más numerosos. Convencidas las huestes cristianas de la derrota, divisaron una cruz luminosa sobre una encina que les dio fuerzas para resistir hasta la llegada de refuerzos. Conforme a Vagad, "sus elementos fueron las primeras armas de los reyes de Sobrarbe": Vagad 1996.

${ }^{66}$ Zurita [1562-1580] 1980. Retoma la hipótesis Castillo 1985, pp. 525-538.

${ }^{67}$ Primero expuso su teoría en Menéndez Pidal 1955, pp. 126-133.

${ }^{68}$ Según advierte Montaner 1995, p. 18.
} 

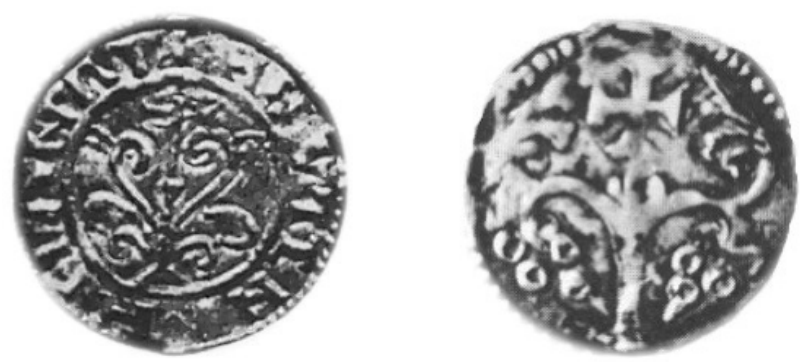

Fig. 9. a) Dinero de Canuto el Grande, anterior a 1035. Reverso.

b) Diner episcopal de Gerona (934-970). Reverso.

La búsqueda de monedas similares en el entorno europeo occidental ha tenido como resultado el hallazgo de unas piezas que, escasas, corroboran que debe descartarse la función emblemática: por un lado, unos dineros daneses atribuidos a Canuto el Grande (1018-1035), de los que se han encontrado cinco ejemplares ${ }^{69}$ y, por otro, los efímeros diners episcopales batidos en Girona algo más tarde, se supone que poco después de $1052^{70}$. Nada permite enlazar este tipo de acuñaciones entre sí, aunque merece la pena señalar que casi coetáneamente, y en Oriente, emitieron con este tipo particular los emperadores bizantinos Miguel VII (1067-1078) y Nicéforo III (1078-1081) ${ }^{71}$, acaso tomando para una de las caras de sus amonedaciones unos motivos que, desde la primera mitad del siglo X hasta inicios del XI, habían sido relativamente frecuentes en la sigilografía de los altos funcionarios imperiales, mayoritariamente los que ostentaban relevantes cargos de carácter militar ${ }^{72}$; esto es, la cruz, usualmente sobre tres escalones, con florecientes ramajes a ambos lados ${ }^{73}$. No es posible asegurar la efectiva circulación de estas monedas orientales en territorios

\footnotetext{
${ }^{69}$ Estas monedas serían de finales de su reinado y su anverso ha sido definido como "el tipo clásico de reverso navarro-aragonés: cruz sobre alto vástago entre dos ramas adornada, en formación": Thomsen 1956, pp. 75-77. Sospecha que son copia de las aragonesas, pero la cronología parece impedirlo.

${ }^{70}$ Balaguer 1999, pp. 428 y 430. Había adelantado la fecha, entre 934 y 970, Crusafont 1982, p. 170. Luego Ramón Berenguer III (1096-1131) emitiría con este tipo particular en Osona: Balaguer 1999, p. 418.

${ }^{71}$ Con busto de frente de Cristo y, en el reverso, esta cruz de particulares características.

${ }^{72}$ Desde la primera mitad del siglo X hasta inicios del XI constan sellos de este funcionariado en todo el imperio bizantino. Sobre ellos, Zacos 1984, núms. 78, 79, 84, 88, 92, 94, 95, 103 , 106, 108, 109a, 114, 116, 120, 121, 146, 166, 173a, 180, 188, 198, 214a, 216, 229, 231c, 242bis y 245 y Oikonomides 1985, pp. 12-13.

${ }^{73}$ Mi agradecimiento a Francisco de Asís García, quien llamó mi atención sobre estas improntas.
} 
aragoneses aunque un estudio de Lacarra menciona la presencia ocasional de piezas bizantinas a partir de mediados del $\mathrm{XI}^{74}$, por lo que podría suponerse que estas amonedaciones foráneas pudieron haber sido el origen de este tipo iconográfico en las del rey de Aragón. Por otra parte, aunque sin ahondar sobre ello, no parece aleatorio el trasvase iconográfico que se constata inaugurada la segunda mitad del siglo XI: al tiempo que se confirma que en el mundo bizantino este modelo pierde adeptos de forma gradual, se atestigua su adopción en Occidente, en un momento en el que las tensas relaciones entre ambas zonas ecuménicas culminaban con el llorado e irresoluto Cisma de la Iglesia.
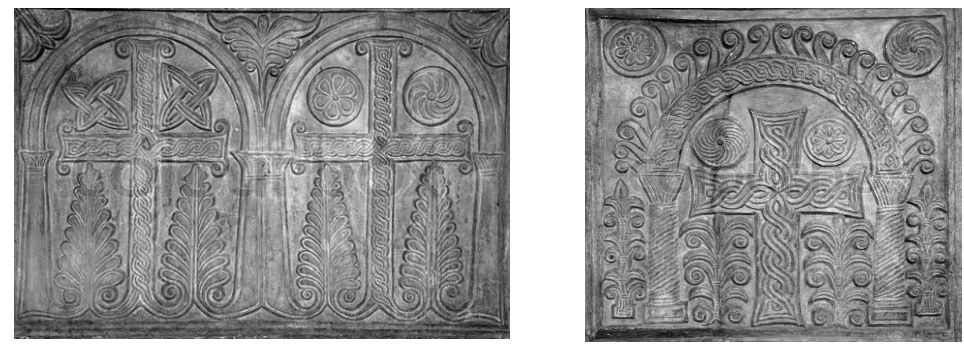

Fig. 10. Ornamentaciones paleocristianas en Santa María in Cosmedin y en Santa Sabina, Roma.

Por otra parte, resulta imposible dejar de aludir a la memoria visual de Sancho Ramírez quien, en su viaje a Roma, pudo haber conocido algunos de los ejemplos esculpidos de los siglos VIII al IX que, luciendo cruces flanqueadas por árboles, todavía hoy se conservan en templos importantes.

Ya hace muchos años que Mann ${ }^{75}$ advirtió sobre lo que pudo haber visto el rey de Aragón durante su estancia en la Ciudad Eterna de acuerdo con los relatos conservados de otros peregrinos. Sigerico, arzobispo de Canterbury que viajó a Roma en 990 para recibir el palio por parte de Juan XV, menciona veintitrés iglesias, entre ellas las basílicas de Santa Sabina y Santa María in Cosmedin, precisamente los lugares donde hoy se conservan más ejemplos de este tipo representativo ${ }^{76}$ : la cruz como árbol de vida, iconografía que alcan-

${ }^{74}$ El testamento de Oriol Íñiguez, de mediados del siglo XI, menciona "Do pro remedio animarum nostrarum ad Sanctum Petrum de Roma nonaginta nummos aureos et I grecisco": Lacarra 1950, p. 57. Documento en Viruete 2011, vol. II, núm. 216.

${ }^{75}$ Mann 1953, p. 122.

${ }^{76}$ Recuérdese el Schola cantorum de Santa Sabina que, aunque recompuesto en 1936, utiliza piezas del siglo V al IX. O la losa funeraria del siglo VIII de Santa María in Cosmedin, ahora cancel del coro. 
zará un hito artístico, aunque ya a en los albores del siglo XII, en el precioso conjunto musivar de la cabecera de San Clemente. No especularé sobre lo que vio el rey durante su estancia y hasta qué punto lo que vislumbró impactó su retina, pero que existieron estas decoraciones de raigambre paleocristiana en las más importantes basílicas romanas es un hecho ${ }^{77}$, del mismo modo que también lo es la difusión de su uso en el siglo XII.

Antes de concluir con este epígrafe, tras descartar que esta cruz ornamentada de Sancho Ramírez remite a la tipología à la croix, y una vez comprobado que está desprovista de cualquier signo personal o dinástico, aludiré brevemente a sus ramificaciones, para algunos insólitas y que, a todas luces, presentan a la cruz como árbol de la vida. Entre los primeros escritores cristianos, resulta elocuente destacar a Nacianceno quien, reconocido como el más completo estilista retórico de la patrística del siglo IV $^{78}$, compuso diversas piezas pías de exaltación, entre otros, a la Cruz. De él se han conservado homilías y otras invocaciones copiadas a finales del IX, y, por tanto, inmediatas a las primeras improntas céreas bizantinas comentadas, cuyos pergaminos han recibido decoración iluminada ${ }^{79}$ que exhibe idénticas cruces flanqueadas por ramas floronadas. No hay duda sobre su significación, pues el parangón del madero de la cruz con el árbol del paraíso inunda varios de sus versos ${ }^{80}$. Concluiré con una llamada de atención con respecto a la fértil transmisión del modelo de este tipo de cruz que, a lo largo de este período que culmina mediado ya el siglo XI, se constata entre los diversos soportes artísticos: miniatura, sigilografía, numismática, e incluso tejidos de carácter sacro ${ }^{81}$ exhibirán esta portentosa cruz que en el caso aragonés, como expondré a continuación, alcanzará una suerte de asimilación con la institución monárquica.

${ }^{77}$ Derivadas del conocido como primer renacimiento artístico en Roma, donde se unieron diferentes motivos de origen clásico, paleocristiano, bizantino y oriental. Sobre ello, remito al fundamental Krautheimer 1980.

${ }^{78}$ Sobre su obra, aún es de actualidad Ruether 1969.

${ }^{79}$ En concreto las Homilías de Gregorio Nacianceno, de 879-882. BnF (Ms. Grec 510, f. C).

80 "Dios, como quería reconstruir al hombre, vino como Dios en la naturaleza humana, para que, luchando e hiriendo de muerte al homicida y venciendo con el gusto de la hiel el fruto prohibido, con las heridas de los clavos las manos que habían cometido el acto nefasto, con la cruz del árbol del paraíso terrenal y con su sublimidad la tierra, pudiera restituir a Adán redivivo a su vida y a su gloria": Nacianceno, Cármina, pp. 162 y ss. Más elocuente es el Himno I de La Devoción de la Cruz a la que, tras invocar: "Oh, Cruz fiel, árbol único en nobleza", se responde: "Jamás el bosque dio mejor tributo en hoja, en flor y en fruto". En Albelda, íntimamente vinculado a la monarquía, hubo composiciones figurativas alusivas a la cruz, con inscripciones que las acompañaban: "Arbor uitae largire praecibus Sanctionis o Amomum crucis flos sacre adfla Ranimirum", del poema 2, o "Arbor pardis tensa ramis hincue siue et hinc", del tercero, lo corroboran. Las referencias son de Díaz 1979, pp. 354 y 356; 1981.

${ }^{81}$ Como ejemplifica el saquito-relicario del Nationalmuseum de Nürnberg fechado en Bizancio hacia 1051-1100. Trabajado en seda y plata con hilo de oro, perlas y almanditas, presenta cruz de doble travesaño flanqueada por imponentes ramificaciones (Negr. Nr. GNM KG 562). 


\section{LA CRUZ Y SU VÍNCULO CON LA CASA REAL DE ARAGÓN}

Dando por sentado que la cruz constituye el referente principal de la veneración de los fieles cristianos y que fue un símbolo de amplísima difusión en todos los géneros artísticos, podemos afirmar, no obstante, que su adopción en las primeras monedas del rey de Aragón respondió a una voluntad que iba más allá que la puramente devocional. Receptora de contenidos políticos, en poco tiempo fue asumiendo nuevos significados que derivaban de una doble percepción: la del rey como nuevo Constantino y la de la Reconquista como Cruzada.

Carecemos de apoyo documental del momento que corrobore la asimilación entre Sancho Ramírez y Constantino, pero hace algún tiempo que Simon advirtió la referencia a este emperador en el tímpano de la catedral de Jaca, edificio emblemático, como ya se ha señalado aquí aunque brevemente, de este reinado. No es casual que esta edificación, con tantas particularidades constructivas y decorativas ${ }^{82}$, fuese concebida originariamente con una cubrición que remitía a las primeras basílicas cristianas ${ }^{83}$ y, en concreto y de acuerdo con el americano, a San Pedro de Roma, precisamente erigida por aquel emperador ${ }^{84}$ y que tanto pudo admirar Sancho Ramírez cuando, en 1068 acudió a Roma para infeudar su reino a la Santa Sede.

El entendimiento entre Sancho Ramírez y el Santo Padre fue equitativo. Quienes han trabajado sobre el asunto confirman que una de las consecuencias del vasallaje fue, por parte del rey, la de obviar la dependencia con respecto a la monarquía pamplonesa y conseguir una vinculación externa de prestigio que avalara el nuevo reino ${ }^{85}$. Por parte de Gregorio VII, la de encontrar un nuevo aliado para la expansión de la cristiandad a costa del Islam que supusiera una recuperación del patrimonium Sancti Petri. Muy clarificadora es, en este sentido, la carta que, en 1073, enviaba a los nobles franceses dispuestos a participar en una campaña en la Península en la que subrayaba que estos territorios habían pertenecido desde antiguo a su jurisdicción y que, aunque ahora ocupados por los paganos, todavía le pertenecían por ley de justicia a la Sede Apostólica solamente ${ }^{86}$. A este primer

${ }^{82}$ Sobre esta cuestión, Martínez de Aguirre 2011, pp. 213-229.

${ }^{83}$ Ya sugerido por Lacarra 1993, p. 16.

${ }^{84}$ Simon 2011, p. 387.

${ }^{85}$ García-Guijarro 2004, pp. 247-248. Esta dimensión política del viaje entra en contradicción con la hipótesis de Kehr, quien lo consideraba como un acto de devoción y de entrega personal: Kehr 1946, p. 94.

86 "Non latere vos credimus regnum Hyspanie ab antiuo propii iuris sancti Petri fuisse et adhuc, licet diu a paganis sit occupatum lege tamen iustitie non evacuata, nulli mortalium sed soli apostolice sedi ex equo pertinere": Caspar 1955, p. 11. También, Ubieto 1991, pp. 174-175. 
reclamo del papado por la soberanía de las tierras hispanas le sucedería la voluntad de abolir en ellas la liturgia mozárabe, a lo que Sancho Ramírez y su entorno responderían favorablemente y de inmediato ${ }^{87}$. Poco después, el 28 de junio de 1077, el Papa volvía a hacer el reclamo de pertenencia en una carta pastoral a los regidores de España en la que evocaba los deberes del príncipe cristiano y las responsabilidades de este cargo y, además, aludía a unos antiguos decretos que legitimaban su exigencia ${ }^{88}$, ius propietatem esse traditum que han sido relacionados por Cowdrey con el texto de la Constantini Constitutum por la cual el emperador Constantino habría cedido al papa Silvestre I todas las provincias de Italia y las demás regiones del oeste del Imperio romano ${ }^{89}$. No resulta extraño que Constantino, para gran parte de la historiografía ejemplo de docilidad y humildad ante el poder espiritual ${ }^{90}$, fuese reivindicado en tiempos de la reforma gregoriana, y aún menos asimilado como paradigma a seguir por los monarcas medievales ${ }^{91}$, entre otros el aragonés: uno de los últimos trabajos de García García va en esta línea interpretativa ${ }^{92}$.

En un contexto de reivindicación regia y de cruzada se articulan, pues, nuevos contenidos en torno a la cruz, elemento que, a partir de Sancho Ramírez, se convertirá en un mecanismo de proclamación monárquica. Como queda dicho, fue escogida como signo fáctico que acompañó la imagen figurativa del soberano en uno de los vehículos propagandísticos más efectivos: la moneda, el objeto oficial de uso público y de curso legal por antonomasia. Pero el símbolo crucífero no sólo afectó a este tipo de soporte oficial, sino que también se desplegó en otras promociones vinculadas a la realeza para mostrar a la monarquía como defensora de la fe cristiana y a su representante como gobernante cristianísimo. Pero también, como se verá, fue utilizada con una función de autoafirmación y de fortalecimiento institucional.

\footnotetext{
${ }^{87}$ Sobre la introducción del rito romano en la Península, Soto 1991,pp. 161-174.

88 "Preterea, notum vobis fieri volumus, quod nobis quidem tacere non est liberum, vobis autem non solum ad futuram, sed etiam ad presentem gloriam volde necessarium, videlicet regnum Hyspanie ex antiquis constitutionibus beato Petro et sancte Romane ecclesie in ius propietatem esse traditum": Caspar 1955, pp. 345-346.

${ }^{89}$ Cowdrey 1998, p. 469. Sobre las relaciones políticas del papado a finales del siglo XI, Gordo 2008, pp. 519-559.

${ }^{90}$ Interpretación que descubre a un Constantino como jefe de su iglesia es la de Iogna-Prat 2003, p. 206.

${ }^{91}$ Cowdrey 1997.

${ }^{92}$ García García 2012,pp. 221-229.
} 


\subsection{La ceremonia de coronación: el rey como Miles Dei}

Hay que reconocerle a la iglesia hispanogoda su papel en la creación de una teoría de la monarquía que tendrá sus máximas manifestaciones plásticas en las ceremonias y los emblemas que definirán la imagen pública del rey ${ }^{93}$. Dentro del proceso, fue esencial la unción, protocolo ya sugerido por Isidoro de Sevilla en sus Etimologías: sagrado ungüento para poder ungir a los que estaban llamados al sacerdocio o asumir el poder real ${ }^{94}$. Este fue el modelo que siguió García Sánchez III el de Nájera en 1043 cuando se declaró unctus a Domino ${ }^{95}$, primera referencia documental de este tipo de liturgia en el reino de Pamplona.

Del protocolo visigodo, además de enviado de Dios, o ángel de Dios como definiría Bango ${ }^{96}$, los monarcas navarros también tomaron el título de su fiel soldado; Miles Dei. Conforme al Ordo quando rex cum exercitu ad prelium egreditur, a modo de insignia regia, antes de partir al combate, se desarrollaba un ceremonial en el que, mientras se cantaba una antífona, el diácono tomaba del altar una cruz áurea con un lignum crucis y la entregaba al obispo para que éste la concediese al rey ${ }^{97}$, momento a partir del cual se efectuaba la benedictio crucis $^{98}$. Esta solemnidad parece que fue muy pronto adoptada por los monarcas asturianos, quienes entendieron que por su intercesión vencerían al enemigo, de modo que, según advierten las inscripciones conservadas, esta cruz se convirtió rápidamente, y como ya lo había sido de Constantino conforme a la tradición, en el lábaro de la lucha contra el infiel, tantas veces aquí concebida como guerra sant ${ }^{99}$. Referencias escritas que aludan al rey navarro como Miles Dei pueden encontrarse en los códices Albeldense y Emilianense, cuyos renglones ensalzan a García Sánchez por su inquebrantable veneración a la fe de Cristo y por mostrarse, en todas sus acciones, como magnífico guerrero contra las gentes de los ismaelitas ${ }^{100}$, aptitudes que, en Vigila, también se hacen extensivas a Ramiro (970-c. 991), de quien destaca, en un curioso poema figurado, Cristo, Ramiro es

\footnotetext{
${ }_{93}^{93}$ Cuestión abordada, desde Leovigildo y culminando en su reinterpretación por parte de Alfonso II, en Bango 1992, pp. 19-32.

${ }^{94}$ Fragmento de Bango 2000, p. 24.

${ }^{95}$ En una carta de arras entregada a Estefanía por su marido, García el de Nájera: Rodríguez de Lama 1976, núm. 3, p. 249. Sobre la sacralización de la guerra en el reino de Pamplona del siglo, Miranda 2011, pp. 225-243.

${ }^{96}$ Bango 2000, p. 26.

${ }^{97}$ Liber Ordinum, LXXXIV, cols. 199-200 (Férotin 1904); Puertas 1975, pp. 105-106 y 238. Referidos en López de Guereño 2000, p. 378, n. 15.

${ }^{98}$ Ibidem, n. 16.

${ }^{99}$ Bango 1989, p. 34. No existe documento que corrobore la utlización del Ordo quando... por los reyes asturianos, lo que obliga a mantener cierta cautela al respecto.

${ }^{100}$ Ruiz de la Peña, Moralejo 1985, p. 263.
} 
tu soldado. Tu ángel bueno Ramiro es fuerte, Dios ${ }^{101}$. Ángel de Dios y soldado de Cristo, títulos que la iglesia ya había concedido a los monarcas visigodos y que ahora se trasladaban al rey de Viguera, de la órbita navarra, a finales del siglo X.

Un experto liturgista que manejaba con precisión y originalidad fuentes hispánicas y ultrapirenaicas nos proporciona un ejemplo textual aragonés que corrobora la celebración de esta liturgia que tiene que ser entendida como un ritual verdadero y no sólo ilustrativo del poder del rey; es decir, que tenía, como afirmó Laliena, capacidad para persuadir y generar adhesión ${ }^{102}$. El Sacramental de Roda, aunque no es un Liber Ordinum ${ }^{103}$, contiene algunas bendiciones integrables en la ceremonia de remisión de la cruz relicada al rey y al ejército antes de la expedición, al tiempo que suma otras bendiciones sobre el soberano cuando preside un sínodo o para ser dichas en cualquier tiempo y, en especial, para los benefactores de los nuevos templos ${ }^{104}$. Todos ellos textos que evidencian el manejo de material bíblico en beneficio de la retórica monárquica, no pocas veces redactada y leída públicamente por los clérigos a lo largo de estas liturgias que proclamaban y realzaban al soberano al enlazarlo, mediante textos, gestos e insignias, con lo divino.

Por otra parte, recordaba García García que en el Himnario de Hues$c a$, escrito quizás en Moissac a finales del XI y destinado a San Juan de la Peña, se recoge el himno Vexilla regis de Venancio Fortunato en el oficio de Pasión ${ }^{105}$. Este himno aclama que por la Cruz de Cristo será definitivamente establecido el Reino de Dios ${ }^{106} \mathrm{y}$, mientras que sus primeros versos asocian los estandartes regios con la cruz, los últimos concluyen con una invocación a la Trinidad $^{107}$. En abril de 1085 Sancho Ramírez establecía la obligación a todos sus descendientes de pasar en el cenobio pinatense los días de Cuaresma ${ }^{108}$, motivo por el cual el joven historiador se preguntaba en qué medida estas asociaciones, teniendo en cuenta la efectiva asistencia de los reyes en aquellas

101 "Miles. O Christe, tuus Ranimirus sic honorem. Angelus bonus tuus Ranimirus vigeat, Deus", en el códice Vigilano, f. 2v según refiere Silva 1980, p. 260, n. 15. Estos términos explicarían la iconografía con connotación bélica de este monarca.

${ }^{102}$ Laliena 2000b, p. 471.

${ }^{103} \mathrm{Su}$ editor lo supone elaborado en Urgell para la sede rotense. Se establece el siguiente ordo: ostiario, exorcista, acólito, subdiácono, diácono, presbíero y obispo: Barriga 1975, pp. $95-108$.

${ }^{104}$ Otra de las invocaciones explicaba que el obispo suplica a Dios, quien ha elegido a los soberanos, que reinarán "por la intercesión de todos los santos colma de riquezas a este rey con su ejército y únelo con firme estabilidad al trono del reino (...). Sé para él una loriga contra las formaciones enemigas, un yelmo contra las adversidades, paciencia contra los improperios, un eterno escudo para su protección". Párrafo CI, procedente de Laliena 2000b, pp. 472-473.

${ }^{105}$ En los ff. 22v-23v conforme a Durán 1987,pp. 58-59 según cita García García 2012, p. 233.

106 "Regnavit a ligno Deus": Fortunato, Hymnus Vexila Regis, PL, 88, 96.

${ }^{107}$ García García 2012, p. 233.

${ }^{108}$ Briz Martínez 1620, p. 555, citado en Ubieto 1951, p. 82, n. 31. 
celebraciones pascuales y con la liturgia como fondo, pudieron influir en una concepción sacralizada del combate ${ }^{109}$, concepción, claro está, que redundaría en la dilación en el uso de determinados emblemas de sacro contenido.

\subsection{La iconografía como elemento documental}

A los testimonios textuales hay que sumarles los restos iconográficos conservados que, del último tercio del siglo $\mathrm{X}$ y en el área de influencia de Pamplona y Aragón, parecen certificar esta íntima relación: los relieves de San Miguel de Villatuerta y los de Luesia son ilustrativos en este sentido ${ }^{110}$.

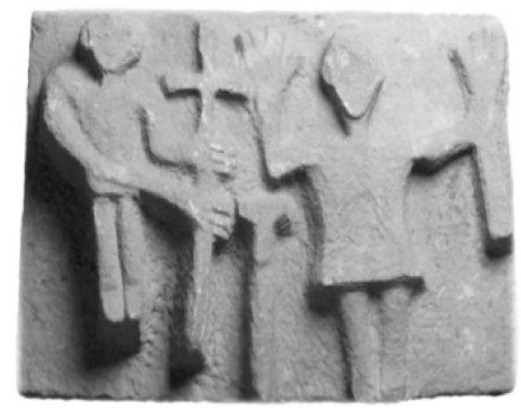

Fig. 11. San Miguel de Villatuerta, Navarra. Último tercio del siglo X.

Fue Fontaine el primero en sugerir, de la escultura de San Miguel de Villatuerta, sus relaciones con el ordo visigótico antes mencionado en el que uno de sus cánones describe el ritual para ir a la guerra ${ }^{111}$, aunque fue Silva quien profundizó sobre ello y quien evidenció que lo que la imagen representaba era, en concreto, el aludido Ordo quando rex cum exercitu ad prelium egreditur $^{112}$. Para la autora, el relieve reproduciría la escena litúrgica en la que la cruz, convertida ahora en estandarte real, era presentada al rey para que éste la ofreciera al presbítero o diácono encargado de portarla durante la campaña ${ }^{113}$.

\footnotetext{
${ }^{109}$ García García 2012, p. 233.

${ }^{110}$ No obstante, se advierte que el sentido real de estos bajorelieves se nos puede escapar en Henriet 2005, p. 175.

${ }^{111}$ Fontaine 1977, p. 255. Estado de la cuestión sobre las lecturas de los relieves en Poza 2000, pp. 609-627.

${ }^{112}$ Silva 1984,pp. 190-192.

${ }^{113}$ Ibidem.
} 
Años después, Martínez de Aguirre apuntó la hipótesis de que este conjunto representaba una metáfora del poder a través de la cual Sancho II pretendía entroncar, emulando a la monarquía astur con la que mantenía parentesco, con los pretéritos monarcas hispanogodos ${ }^{114}$. Así, estos relieves, además de constatar el desarrollo, a finales del X y en el reino navarro-aragonés, de ceremonias reales elaboradas tres siglos antes, trascendían la concreta circunstancia de una campaña guerrera y exhibían un corpus ideológico y político que remontaba los orígenes de los regentes del reino hasta los reyes visigóticos ${ }^{115}$.

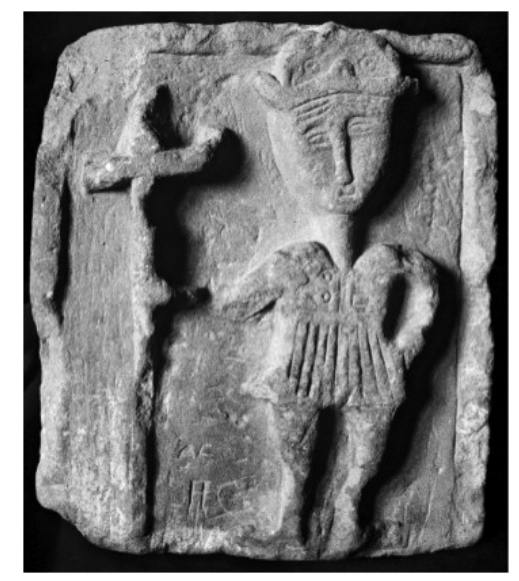

Fig. 12. Relieve de Luesia, Zaragoza. Fechado hacia 975.

Un minucioso estudio de Cabañero y Galtier ${ }^{116}$ confirmó que los relieves de Villatuerta no suponían un unicum: en Luesia se reflejaba ese mismo fragmento del ritual, con lo que demostraron que el Liber Ordinum, que regulaba la dramatización de este acto, era utilizado por los reyes pamploneses con la intención de cumplimentar los ritos guerreros destinados a exaltar su poder ${ }^{117}$. Una liturgia, como queda dicho, modelada con una finalidad propagandística cuyos protagonistas esenciales eran la cruz, ahora convertida en insignia, y el rey. Estoy de acuerdo con Laliena cuando afir-

\footnotetext{
${ }^{114}$ Hipótesis extensiva a las miniaturas de los códices Albeldense y Emilianense: Martínez de Aguirre 1996, en esp.pp. 192-200. Sobre este neogoticismo o panhispanismo, Martín Duque 2004 .

${ }^{115}$ Ibidem, pp. 195-200.

${ }^{116}$ Cabañero, Galtier 1986, pp. 11-28.

${ }^{117}$ Manifiesta la persistencia de estas ceremonias en Castilla y en León, Bronsich 1998, citado en Laliena 2000b, p. 469, n. 11.
} 
ma que este tipo de ceremoniales, lejos de evidenciar la piedad personal de los monarcas, concentraba en la figura del rey el carácter simbólico de la dominación, en particular a través de la vinculación entre la divinidad y el soberano, con lo que se realzaba intensamente la similitud entre el liderazgo terrenal y la preeminencia celestial ${ }^{118}$. Y, para ello, el vínculo visual entre el rey y la Cruz resultaba esencial, motivo por el cual el rey no pocas veces se preocupó de manifestarse, públicamente, en reiteradas ocasiones y mediante los diversos soportes, en relación con este elemento, ahora reconvertido en emblema monárquico.

\subsection{La advocación a la Santa Cruz}

No querría dejar de insistir acerca de la relevancia de la cruz como elemento profiláctico ${ }^{119}$, por lo que el cariz devocional no debe menospreciarse. Mi intención aquí está lejos de difuminar el fervor que los reyes de Aragón mostraron ante una de las más sagradas reliquias que, dicho sea de paso, más relacionadas estaban con Constantino al haber sido su madre, santa Helena, la artífice de su descubrimiento. Los textos aragoneses conservados que detallan las reliquias, su variedad y cantidad, así como también los espléndidos contenedores que las albergaban y que se encontraban en templos importantes de la época vinculados a la casa real, aluden a la presencia de fragmentos u objetos relacionados con la cruz o el Nazareno, a quien Sancho Ramírez demostró especial devoción al final de su reinado: recuérdese que, entre otras disposiciones, en 1086 había creado la canónica de Jesús Nazareno en Montearagón ${ }^{120}$.

Muy ilustrativo es el testimonio documental que nos ha llegado acerca de la consagración, en 1094, de la iglesia de San Juan de la Peña, llevada a cabo el primer año en el que fue rey de Pamplona y Aragón Pedro I, quien se hallaba presente en el solemne acto. En la descripción de las numerosas reliquias de la iglesia del monasterio constan, entre las del altar de San Juan

\footnotetext{
${ }^{118}$ Ibidem, p. 471.

${ }^{119}$ Sentido que se mantuvo con el paso del tiempo. Ilustrativos son los términos de Jiménez de Rada quien, anotando lo sucedido durante el combate del 16 de julio de 1212 explica: "La cruz del Señor, que solía tremolar delante del arzobispo de Toledo, pasó milagrosamente entre las filas de los agarenos (...) y allí tal como quiso el Señor, permaneció hasta el final de la batalla sin que su portador, solo, sufriera daño alguno": Fernández Valverde 1989, p. 320. No obstante, estoy de acuerdo con Herniet cuando advierte que debe relativizarse la intencionalidad bélica anti-islámica atribuida a numerosas cruces de orfebrería hispanas: Henriet 2005, pp. 168-172. Sobre estas cruces en la Península, García de Castro 2009, pp. 371-400.

${ }^{120}$ Tres años después fue tomada bajo la protección de la Santa Sede por Urbano II: Durán 1987, pp. 12 y 20.
} 
Bautista, reliquias provenientes del sepulcro del Señor; entre las del arca sobre la de San Indalecio, se guardaban las

de la cruz del Señor, de la túnica del Señor, del pan de Cristo, del lienzo con el que Cristo secó los pies de sus discípulos. Traídas de las tierras de Jerusalén se contienen las siguientes: del pesebre del Señor, del lugar de la Transfiguración, del templo, del monte Calvario, de petrone del Señor ${ }^{121}$.

La veneración de Pedro hacia las reliquias cristológicas fue demostrada dos años después cuando consagraba la mezquita mayor de Huesca en honor de Iesuchristo Nazareno ${ }^{122}$. Que la dedicación de la mezquita fue in honore domini nostri Ihesu Christi Nazareni lo expresan el privilegio de Pedro I de 1096, la bula de Urbano II de 1098 y confirmada por Gregorio VIII, y otro privilegio de ese mismo año del monarca y fechado en el asedio del castillo de Calasanz ${ }^{123}$. No parece casual la elección del culto en la Huesca conquistada pues, poco antes, en noviembre de 1095, los cristianos hubiesen tomado la cruz de Cristo en Clermont bajo el grito proclamado por Urbano II durante el sermón para la liberación de Jerusalén: Deus lo volt o Cristo mismo lo manda ${ }^{124}$. Que el rey Pedro respondió a este mismo espíritu lo corrobora una de las fortalezas de las que se sirvió para intentar la conquista de la ciudad de Zaragoza, defensa bautizada Juslibol. No obstante, la victoria tendría que esperar: esta ciudad no fue conquistada hasta diciembre de 1118, unos meses después de que un concilio celebrado en Tolouse le otorgara la categoría de cruzada.

Los reyes nunca olvidaron el arbotante moral que, para las conquistas, les supuso el beneplácito divino: en el documento de privilegio de la catedral de Huesca Pedro I no titubeó al proclamar públicamente la ayuda que, para él y su predecesor, Sancho Ramírez, les había dispensado el Nazareno ${ }^{125}$.

${ }^{121}$ Fragmentos de Díaz 1979, pp. 319-320.

122 "y de Santa María, su madre, y de San Pedro, Príncipe de los Apóstoles, y de los gloriosos San Iuan Baptista y San Iuan Evangelista, y dotó el Rey la Iglesia de todas las posesiones y rentas que la Mezquita tenía en tiempo de los moros": Zurita [1562-1580], 1980, lib. I, cap. XXXII.

${ }^{123}$ Sobre estos documentos y su autenticidad, Arco, 1951, pp. 36 y ss.

${ }^{124}$ Se conservan cinco versiones del texto que leyó Urbano II en Clermont: el de Fulgerio de Chartres, en Gesta Francorum Jerusalem Expugnantium; el de Roberto el Monje incluido en Historia Hierosolymitana; la versión de las Gesta Francorum, el texto de Baldric de Dol, y el de Guiberto de Nogent Historia quae dicitur Gesta Dei per Francos. Es de interés la carta de Instrucciones que emitió Urbano II en diciembre de 1095.

125 "Subiungimus etiam ad honorandum altare Ihesu Nazareni, qui mihi et patribus meis gloriossas concessit victorias": Ubieto 1951, doc. 30, p. 253. Véase también Laliena 2000a, pp. 262-263. 
Y aunque es cierto que el autor del Codex Valentinus ${ }^{126}$ afirmó que esta advocación era equivalente a la del Salvador, y que un reciente estudio de Martínez de Aguirre concluye que en la Edad Media se identificó el culto de la Cruz con el Santo Sepulcro ${ }^{127}$, nada permite confirmar la identidad entre todas estas celebraciones. No obstante, señalaremos la coincidencia de la adoración, en la festividad nuclear del año litúrgico cristiano que es la celebración del Viernes Santo, de la Cruz, del Nazareno y del Sepulcro del Señor.

Sea cierta o no esta hermandad devocional, no hay duda de la efectiva advocación a las reliquias cristológicas y, en especial, a las relacionadas con la Santa Cruz en consonancia con la lucha contra el infiel. Si el primogénito de Sancho Ramírez, Pedro I, supone un ejemplo en este sentido, no menos ilustrativo es el de su hermano Alfonso I quien, criado en Siresa, donde se constata el culto a un lignum crucis desde comienzos del siglo IX ${ }^{128}$, llevaba en sus campañas militares reliquias de la Vera Cruz:

Siempre traía consigo en campaña un cofre hecho de oro puro adornado con piedras preciosas por dentro y por fuera, en el que había una cruz venerable por las reliquias del madero salvador en el que fue colgado nuestro Señor Jesucristo, hijo de Dios, para redimirnos (...). Y tenía oro, plata y piedras preciosas, llenas de reliquias de Santa María y del madero del Señor ${ }^{129}$.

Algunos de estos sacros objetos podrían haber sido los que se inventariaron en la nueva sede zaragozana entre los llevados allí por Esteban, el obispo de Huesca-Jaca ${ }^{130}$, quien consta que acompañó a Alfonso I en varias expediciones guerreras, entre otras la de Zaragoza de $1118^{131}$.

${ }^{126}$ Colección de inscripciones antiguas, principalmente romanas recogidas en España y Portugal, coleccionadas por Gaspar Galcerán de Pinós y Castro, Conde de Gimerá y sacadas de diversos autores, en especial de Jerónimo Zurita, Florian de Ocampo, Honorato Juan, Martín Velasco Pérez de la Torre, Luis [sic] de Resende, Albiano de Rojas, Juan Alonso Franco, Juan Ginés de Sepúlveda (...), siglos XVI y XVII, 335 ff. BnM, ms. 3610. La noticia sobre la identidad de advocaciones procede de Español 2005-2006, ap. doc.

${ }^{127}$ Martínez de Aguirre 2012,pp. 215-242.

${ }^{128}$ De "ligno crucis" y de "ligno crucis Domini": Ubieto 1986, docs. 2 y 6. Citado en ibidem, p. 242, n. 51 .

129 "Eran guardadas en las tiendas de campaña donde estaba la capilla que siempre estaba situada junto a las tiendas del rey, y los sacerdotes, diáconos y gran parte de los clérigos diariamente las vigilaban y custodiaban, y siempre ofrecían sobre ellas el sacrificio a Dios Nuestro Señor”: Pérez González 1997, p. 79. La costumbre de Alfonso I de llevar reliquias de la Vera Cruz fue advertida por O'Callaghan 2003, p. 193, citado en García García 2012, p. 231, n. 63.

${ }^{130}$ Entre ellas consta un fragmento del lignum crucis: Durán, Moragas 1987, p. 17, citado en García García 2012, p. 231, n. 63.

${ }^{131}$ Le debió de sorprender la muerte en una batalla: Peñart 2002-2003, p. 63. 
Si las reliquias de la Vera Cruz, tantas veces empleadas con fines protectores en campaña, son una evidencia de la advocación a la Santa Cruz por parte de los primeros reyes de Pamplona y Aragón, no menos ilustrativas son las nuevas fundaciones reales instituidas bajo su advocación. Entre ellas sobresale Santa Cruz de la Serós, que pese a haberse fundado bajo la advocación de la Virgen María como recuerda la inscripción de su portada ${ }^{132}$, parece que mantuvo una designación que deriva de la adopción del nombre de la población en que se había erigido la comunidad, aunque tampoco es descartable una doble advocación ${ }^{133}$. Sin duda, además de los interrogantes que plantea la construcción, llama la atención el protagonismo como promotora de doña Sancha quien, de singular personalidad ${ }^{134}$, parece que acompañó a su hermano Sancho Ramírez en sus andanzas conquistadoras. Sin citar las fuentes, Valenzuela la incorpora entre el séquito del rey cuando sitiaba Huesca, al tiempo que también afirma que se hallaba en la batalla de Alcoraz, en la retaguardia, rezando e implorando a Dios para que el triunfo fuese de la cruz ${ }^{135}$, de modo que, si esta fuente fuese fiable, podría rubricarse que el interés por la cruz y su carácter victorioso no sólo se concentró en la figura del rey de Aragón, quien además la empleó en sus signa regis ${ }^{136}$, argumento sobre el que merecería la pena profundizar, sino que se hizo extensivo al entorno áulico.

De acuerdo con lo dicho puede afirmarse que, a finales del siglo XI y en los albores del XII, en el reino de Aragón existió una predilección por la representación de símbolos cristológicos vinculados con la monarquía y que, en función del contexto político, religioso y social, se estimaron como los más convenientes. Es verdad que otras soberanías peninsulares también emplearon estos símbolos, incluso en el mismo soporte: sirvan de ejemplo las emisiones de Alfonso VI y Urraca de Castilla y de León ${ }^{137}$, en cuyo anverso campea una cruz y en su reverso un crismón. Que se encuentre este

\footnotetext{
${ }^{132}$ VIRGINIS HOC TEMPLUM QUISQUIS PENETRARE BEATUM conforme a Lampérez según Oliván 1969, p. 126.

${ }^{133}$ De 1079 fecha un documento donde se menciona Santa Cruz: "cum illa comitissa domina Sancia et cum illis sororibus de Santa Cruce". Es el pergamino 436 copiado al f. 47v del Libro Gótico de San Juan de la Peña conforme a Arco 1913, p. 434. La mención "de Santa Cruce" vuelve a verse en un documento de 1081 firmado por Aznar y su esposa doña Blasquita: ibidem, p. 435. La duplicidad en el nombre se da en documentos del siglo XIII, aunque algunos son copias de otros del XI: Ubieto 1966, docs. 5 y 6, por ejemplo.

${ }^{134} \mathrm{Su}$ papel promotor fue analizado brevemente por McKiernan 2005, pp. 159-165. Sintético y clarificador trabajo en el que se desarrolla un estado de la cuestión sobre quienes han abordado esta figura: Buesa 1995, pp. 17-53.

${ }^{135}$ Valenzuela 1959, p. 128. Pero ni la Crónica de San Juan de la Peña ni Zurita lo corroboran.

${ }^{136}$ La emplearon en sus firmas, por citar a los más inmediatos a Sancho Ramírez, Ramiro I, Pedro I o Ramiro II.

${ }^{137}$ Heiss 1867 (León y Castilla), p. 6.
} 
motivo en el reverso de las monedas castellanas y leonesas se debe, según Heiss, al matrimonio de Alfonso VI con Constanza, sobrina de Enrique I de Francia, quien emitía monedas con este tipo particular ${ }^{138}$. No obstante, en la adopción del crismón en la numismática se ha olvidado de un precedente fundamental; el de Ermengol III de Urgell (1038-1065), quien también batió numerario con este tipo particular. Sus vínculos con Alfonso VI están comprobados y culminarían muy poco después: quien sería el futuro Ermengol V de Urgell (1092-1102), no sólo nacería en León, sino que pasaría su infancia en la corte del rey de León y Castilla ${ }^{139}$. Por otra parte, las relaciones del condado de Urgell con el reino de Aragón se manifiestan muy estrechas sobre todo en tiempos de Sancho Ramírez: aunque anulado en 1068, el aragonés había casado con Isabel de Urgell, hija de Ermengol III hacia 1063, precisamente el año en el que el catalán contraía terceras nupcias con doña Sancha, hermana del rey de Aragón, quien tutelaría a su hijastro Ermengol IV durante su minoría de edad. La intervención en la administración del territorio catalán de la condesa viuda quizás sea la razón que explique, entre otros aspectos del gobierno del futuro conde ${ }^{140}$, la similitud formal e iconográfica entre la numismática del urgellés con algunas de las monedas de Sancho Ramírez y las primeras del reinado de Pedro $\mathrm{I}^{141}$, con quien consta que, además, colaboró a nivel político.

Concluyo evidenciando la importancia de las conexiones entre el condado de Urgell y Aragón, relaciones que, además de familiares y políticas, favorecieron, a mi modo de ver, permeabilidades artísticas que podrán concretizarse con un estudio exhaustivo en este sentido. Dentro de esta vía de análisis, la figura de doña Sancha se revela como esencial. Eco relativo ha tenido su faceta como política, tanto en tiempos de su hermano Sancho Ramírez como en los de su sobrino Pedro I. Si la historiografía ha advertido que en su voluntad primaban los asuntos materiales sobre los espirituales, hay que reconocer que su papel en los asuntos religiosos del reino no fue menos extraordinario. Conforme a Buesa ${ }^{142}$ pudo consumar eficazmente y no de forma esporádica unos cargos ${ }^{143}$ que podrían calificarse de anómalos

${ }^{138}$ Y que era el tipo propio de los capetos: ibidem, p. 4.

${ }^{139}$ Estas buenas relaciones favorecerían el matrimonio de María, hija de Pedro Ansúrez, con el urgellés y el traslado del noble al condado catalán una vez su hija quedó viuda: Rodríguez Fernández 1966.

${ }^{140}$ Como su defensa, en sintonía con los ideales de su madrastra doña Sancha, de la incorporación de la reforma gregoriana en Urgell.

${ }^{141}$ Sobre lo que llamaba la atención Ibáñez 1998, p. 82, n. 5.

${ }^{142}$ Buesa 1995, pp. 17-53.

${ }^{143}$ Fue tenente y gobernadora de Atarés, San Urbez, Santa Cruz y Siresa. Administró algún tiempo la diócesis de Pamplona: Ubieto 1973. 
conforme al Derecho Canónico con el beneplácito del rey y del Santo Padre. Su actividad como firme impulsora de la política reformista de Gregorio VII, y también en tiempos de Urbano II con quien mantuvo relación ${ }^{144}$, ha llevado a que autores como Aurell ${ }^{145}$ la consideren como una de las mayores aliadas del Sumo Pontífice en la Península. Si su labor político-religiosa ha sido poco enfatizada por los estudiosos, menor trascendencia ha supuesto su actuación en la vertiente artística, donde pienso que pudo tener un papel preponderante en la incorporación y/o confirmación de modelos con la intención última de proclamar la institución monárquica personificada, en primera instancia, por su hermano Sancho Ramírez y, a su muerte, por su sobrino Pedro I, con quienes mantuvo, conforme a la documentación conservada, una estrecha y dilatada relación.

\section{BIBLIOGRAFÍA CITADA}

Álvarez Burgos, Fernando (1998), Catálogo de la moneda medieval castellano-leonesa. Siglos XI al XV, vol. III, Madrid, Vico-Segarra.

Amorós Barra, José V. (1954), Estado de la cuestión referente a las monedas navarras de la casa de Navarra (con motivo de una moneda navarra del Gabinete Numismático de Cataluña), "Numario Hispánico" 3, pp. 17-40.

Arco, Ricardo del (1913), Santa Cruz de la Serós, "Linajes de Aragón" 4, pp. 431-455.

Arco, Ricardo del (1951), La mezquita mayor y la catedral de Huesca, "Argensola. Revista de Ciencias Sociales del Instituto de Estudios Altoaragoneses" 5, pp. 35-42.

Aurell Cardona, Martín (1997), Les noces del comte: matrimoni i poder (7851213), Barcelona, Omega.

Babelon, Jean (1953), Retratos monetarios de Fernando el Católico, "Numisma" 7, pp. 67-75.

Balaguer, Anna $\mathrm{M}^{\mathrm{a}}$ (1984), The influence of moslem coinages upon the monetary systems of medieval Iberian Kingdoms, en Marques, Mario Gómes (ed.), Problems of Medieval Coinage in Iberian Area, Santarém, Instituto Politécnico de Santarém, pp. 307-334.

Balaguer, Anna M $\mathrm{M}^{\mathrm{a}}$ (1999), Història de la moneda dels comtats catalans, Barcelona, Societat Catalana d'Estudis Numismàtics - IEC.

\footnotetext{
${ }^{144}$ Apoyo documental referido, entre otros, en Durán 1962, p. 54.

${ }^{145}$ Aurell 1997, p. 525.
} 
Balaguer, Anna Mª; Crusafont, Miquel (1983), Estudi preliminar de la troballa de monedes comtals d'Òrrius (El Maresme), en Padilla, José I.; Vives, Elisenda, Les excavacions a l'església de Sant Andreu (Òrrius). Estudi preliminar de la troballa de monedes comtals, Barcelona, Departament de Cultura de la Generalitat de Catalunya, pp. 59-104.

Bango Torviso, Isidro G. (1989), Alta Edad Media. De la tradición hispanogoda al románico, Madrid, Sílex.

Bango Torviso, Isidro G., (1992), Los reyes y el arte durante la alta Edad Media. Leovigildo y Alfonso II y el arte oficial, "Ephialte. Lecturas de Historia del Arte" 3, pp. 19-32.

Bango Torviso, Isidro G., (2000), El Rey. Benedictus qui venit in nomine Domini, en Bango, Isidro G. (dir.), Maravillas de la España Medieval. Tesoro sagrado y monarquía, León, Junta de Castilla y León - Caja España, vol. I, pp. 23-30.

Barriga Planas, Josep R. (1975), El sacramentari, ritual i pontifical de Roda. Cod. 16 de l'arxiu de la Catedral de Lleida, c. 1000, Lleida, Instituto de Estudios Ilerdenses.

Betrán Abadía, Ramón (1992), La forma de la ciudad. Las ciudades de Aragón en la Edad Media,Zaragoza, Colegio Oficial de Arquitectos de Aragón.

Betrán Abadía, Ramón (1999), El camino de Santiago en Aragón y la ciudad ordenada en Aragón, Zaragoza, Departamento de Educación y Cultura de Aragón.

Beltrán Martínez, Antonio (1972), Recordando a Pío Beltrán con los mancusos de Sancho Ramírez, "Estudios" 1, p. 163.

Beltrán Villagrasa, Pío (1972a), Los dineros jaqueses, su evolución y su desaparición, en Obra Completa, Zaragoza, Universidad de Zaragoza, pp. 397-464.

Beltrán Villagrasa, Pío (1972b), Obras completas, II, Zaragoza, Universidad de Zaragoza.

Bielza de Ory, Vicente (2003), El fuero de Jaca, el Camino de Santiago y el urbanismo ortogonal, en El Fuero de Jaca, Zaragoza, El Justicia de Aragón, vol. II, pp. 267-316.

Botet i Sisó, Joaquín (1908-1911), Les monedes catalanes, 3 vols., Barcelona, IEC [consultada la reedición de 1976].

Briz Martínez, Juan, Abad (1620), Historia de la fundación y antigüedades de San Juan de la Peña, Zaragoza, Iván de Lanaja y Quartanet.

Brooke, George C. (1950), English coins from seventh century to the present day, Londres, Methuen and Co.

Bronsich, Pierre A. (1998), Reconquista und Heiliger Krieg. Die deutung des Krieges im Christlichen Spanien von den Westgoten bis ins frühe 12. Jahrhundert, Münster, Aschendorff. 
Buesa Conde, Domingo (1995), Doña Sancha, una infanta al servicio de Aragón, en Buesa, Domingo; Simon, David L., La condesa Sancha y los orígenes de Aragón, Zaragoza, Boira, pp. 17-53.

Cabañero Subiza, Bernabé; Galtier Martí, Fernando (1986), Tuis exercitibus crux Christi semper adsistat. El relieve prerrománico de Luesia, "Artigrama" 3, pp. 11-28.

Calicó, Francesc X. (1982), Un importante hallazgo en la iglesia parroquial de Orrius (Barcelona), "Gaceta Numismática" 64, pp. 31-32.

Campo, Marta (coord.) (1998), La imatge del poder a la moneda, Barcelona, Museu Nacional d'Art de Catalunya.

Canto García, Alberto (1998), La moneda, instrumento fiscal y eje del encuadramiento político, en El Islam y Cataluña, Barcelona, Lunwerg.

Caspar, Erich (1955), Das Register Gregors VII, Berlin, Weidmannsche Buchhandlung.

Castillo Genzor, Adolfo (1985), Los blasones del reino de Sobrarbe: Aragón y sus raíces heráldicas, "Hidalguía. La revista de genealogía, nobleza y armas" 190-191, pp. 525-538.

Cowdrey, John (1997), Eleventh-century Reformers' views of Constantine, "Byzantinische Forschungen" 24, pp. 63-91.

Cowdrey, John (1998), Pope Gregory VII. 1073-1085, Oxford, Oxford University Press.

Crusafont i Sabater, Miquel (1982), Numismática de la Corona CatalanoAragonesa medieval (785-1516), Madrid, Vico.

Crusafont i Sabater, Miquel (1992), Acuñaciones de la Corona Catalano-Aragonesa y de los reinos de Aragón y Navarra. Medioevo y tránsito a la Edad Moderna, en Catálogo General de las monedas españolas, vol. IV, Madrid, Vico y Segarra.

Díaz y Díaz, Manuel C. (1979), Libros y librerías en la Rioja altomedieval, Logroño, Instituto de Estudios Riojanos.

Díaz y Díaz, Manuel C. (1981), Vigilán y Sarracino: sobre composiciones figurativas en la Rioja del siglo X, en Berschin, Walter; Düchting, Reihard, Lateinische Dichtungen des X. und XI Jahrhunderts. Festgabe für Walter Bulst, Heidelberg, L. Schneider, pp. 59-92.

Durán Gudiol, Antonio (1962), La iglesia en Aragón durante los reinados de Sancho Ramírez y Pedro I (1062?-1104), Madrid, Iglesia Nacional Española.

Durán Gudiol, Antonio (1987), El castillo abadía de Montearagón, Zaragoza, Institución Fernando el Católico.

Durán Gudiol, Antonio; Moragas, Ramón (1987), Hymnarium oscense (s. XI), vol. 2, Zaragoza, Institución Fernando el Católico. 
Engel, Arthur; Serrure, Raymond (1890), Traité de Numismatique du Moyen Age, París, Arnaldo Forni.

Español Bertrán, Francesca (2005-2006), El castillo de Loarre y su portada románica, "Locus Amoenus" 18, pp. 7-18.

Eusebio de Cesarea (1994), Vida de Constantino, Introducción, traducción y notas de Martín Gurruchaga, Madrid, Gredos.

Falcón Pérez, M. Isabel (1994), Una ciudad de franquicia: Jaca, en Sancho Ramírez y su tiempo. 1064-1094, Huesca, Instituto de Estudios Aragoneses, pp. 122-124.

Fernández Valverde, Juan (1989), Rodrigo Jiménez de Rada. Historia de los hechos de España, Madrid, Alianza.

Férotin, Marius (1904), Le Liber Ordinum en usage dans l'Église wisigothique et mozarabe d'Espagne du cinquième au onzième siècle, París, Firmin Didot and Cie.

Fontaine, Jacques (1977), L'art préroman hispanique. L'art mozarabe, La Pierre-qui-vire (Yonne), Zodiaque.

Francisco Olmos, José M. de (1998), El maravedí de oro de Alfonso VIII: un mensaje cristiano escrito en árabe, "Revista General de Información y Documentación" 8/1, pp. 283-301.

García de Castro Valdés, César (2009), Génesis y tipología de las cruces de orfebrería en la Edad Media, en Fernández, Javier; García de Castro, César (eds.), Poder y simbología en Europa, siglos VIII-X. Actas del Symposium internacional, Oviedo, 22-27 de septiembre 2008, Gijón, Ediciones Trea, pp. 371-400 (Territorio, Sociedad y Poder. Anexos; 2).

García García, Francisco de Asís (2012), Dogma, ritual y contienda: arte y frontera en el reino de Aragón a finales del siglo XI, en Martos, Juan; Bueno, Marisa (eds.), Fronteras en discusión, Madrid, Almudayna, pp. 217-250.

García-Guijarro Ramos, Luis (2004), El papado y el reino de Aragón en la segunda mitad del siglo XI, “Aragón en la Edad Media” 18,pp. 245-264.

Gil Farrés, Octavio (1955), Estudio crítico de las primitivas acuñaciones navarras y aragonesas, "Numisma" 14, pp. 31-96.

Gil Farrés, Octavio (1974), Historia universal de la moneda, Madrid, Prensa Española.

Gordo Molina, Ángel (2008), Papado y monarquía en el reino de León. Las relaciones político religiosas de Gregorio VII y Alfonso VI en el contexto del Imperium Legionense y de la implantación de la reforma pontifical de la Península Ibérica, "Studi Medievali" 2, pp. 519-559.

Grierson, Philip (1976a), Monnaies du Moyen Age, París, Bibliothèque des Arts. 
Grierson, Philip (1976b), Symbolism in early medieval charters and coins, en Simboli e simbologia nell'alto medioevo. Settimane di studio del Centro Italiano di Studi sull'alto medioevo, Spoleto, Centro Italiano di Studi sull'Alto Medioevo, pp. 1-40.

Heiss, Aloïs (1867), Descripción general de las monedas hispano-cristianas desde la invasión de los árabes, Zaragoza, Luis Marquina y Marín.

Henriet, Patrick (2005), MILLE FORMIS DAEMON. Usages et fonctions de la croix dans l'Hispania des IXe-IXe siècles, en Deswarte, Thomas; Sénac, Phillippe (coords.), Guerre, pouvoirs et idéologies dans l'Espagne chrétienne aux alentours de l'an mil, Turnhout, Brepols, pp. 163-182.

Hernández-Canut, León (2005), El primer retrato regio en la moneda castellana, en Alfaro, Carmen; Marcos, Carmen; Otero, Paloma (coords.), Actas del XIII Congreso Internacional de Numismática, Madrid, Ministerio de Cultura, pp. 1199-1203.

Ibáñez Artica, Miguel (1993), Consideraciones sobre las primitivas monedas de Pamplona-Navarra, "Numisma" 232, pp. 109-145.

Ibáñez Artica, Miguel (1993-1994), Catálogo numismático de Navarra I: monetarios del Museo de Navarra y del Museo Arqueológico Nacional hasta 1305 (tipología Románica: siglos XI-XIII, "Trabajos de Arqueología Navarra" 11, pp. 141-197.

Ibáñez Artica, Miguel (1998), Estudio metalográfico de monedas medievales: Reino de Pamplona-Navarra, siglos XI-XIII, "Numisma” 241, pp. 59-93.

Iogna-Prat, Dominique (2003), La construction biographique du souverain carolingien, en Henriet, Patrick (ed.), À la recherche de légitimités chrétiennes. Représentations de l'espace et du temps dans l'Espagne médiévale (IXe-XIIIe siècle), Lyon, Cahiers de linguistique et de civilisation hispaniques médiévales, pp. 197-224.

Iruña, P. Germán de (1935), Discutibles interpretaciones de la moneda de Sancho el Mayor, "Revista Internacional de Estudios Vascos" 26, pp. 655-660.

Isla Frez, Amancio (2011), Identidades y goticismo en época de Alfonso III: las propuestas de la Albeldense, "Territorio, Sociedad y Poder" 6, pp. 11-21.

Jusué Simonena, Carmen; Ramírez Vaquero, Eloísa (2002), La moneda en Navarra, Pamplona, Gobierno de Navarra.

Kehr, Paul (1946), El papado y los reinos de Navarra y Aragón hasta mediados del siglo XII, Zaragoza, E. Berdejo (Estudios de Edad Media de la Corona de Aragón. Sección de Zaragoza; 2).

Krautheimer, Richard (1980), Rome. Profile of a City, 312-1308, Princeton, Princeton University Press. 
Lacarra Ducay, Mª Carmen (1993), Catedral y museo diocesano de Jaca, Bruselas, Musea Nostra.

Lacarra, José M. (1950), Un arancel de aduanas del siglo XI, Zaragoza, Instituto de Estudios Pirenaicos.

Laliena Corbera, Carlos (1996), La formación del Estado feudal. Aragón y Navarra en la época de Pedro I, Huesca, Estudios Altoaragoneses.

Laliena Corbera, Carlos (2000a), Pedro I de Aragón y de Navarra, Burgos, La Olmeda.

Laliena Corbera, Carlos (2000b), Rituales litúrgicos y poder real en el siglo XI, “Aragón en la Edad Media" 16, pp. 467-476.

Laliena Corbera, Carlos; Sénac, Philippe (1991), Musulmans et Chrétiens dans la Haut Moyen Âge: aux Origines de la Reconquête aragonaise, Montrouge, Minerve.

Lapeña Paúl, A. Isabel (2004), Sancho Ramírez. Rey de Aragón (¿1064?1094) y rey de Navarra (1076-1094), Gijón, Trea.

Lavoix, Henry (1891), Catalogue des monnaies musulmanes de la Bibliothèque Nationale, vol. III, París, Henry Lavoix.

Lluís y Navas-Brusi, Jaime (1956), La función del Mediterráneo en la Historia monetaria, "Numisma" 19, pp. 33-49.

López de Guereño, M ${ }^{\mathrm{a}}$ Teresa (2000), La cruz y el crucificado en la Edad Media hispana, en Bango, Isidro G. (dir.) Maravillas de la España Medieval. Tesoro sagrado y monarquía, León, Junta de Castilla y León - Caja España, vol. I, pp. 371-381.

Mann, Janice (1953), Romanesque Architecture and its Sculptural Decoration in Christian Spain. 1000-1120. Exploring Frontiers and Defining Identities, Toronto, University of Toronto Press.

Marot Salsas, Teresa (1997), La moneda medieval, moderna i contemporània. Els bitllets, en Barral i Altet, Xavier (dir.), Ars Cataloniae, Art de Catalunya, vol. 12, Disseny. Vestit. Moneda i Medalles, Barcelona, L'Isard, pp. 259-260.

Martín Duque, Ángel (2004), Sancho III el Mayor de Navarra, entre la leyenda y la historia, en Ante el milenario del reinado de Sancho el Mayor. Un rey navarro para España y Europa, Pamplona, Institución Príncipe de Viana, pp. 19-41.

Martínez de Aguirre, Javier (1996), Creación de imágenes al servicio de la monarquía, en Martín, Ángel (dir.), Signos de identidad histórica para Navarra, Pamplona, Caja de Ahorros de Navarra, vol. I, pp. 187-202.

Martínez de Aguirre, Javier (2011), Arquitectura y soberanía: la catedral de Jaca y otras empresas constructivas de Sancho Ramírez, "Anales de Historia del Arte" vol. extra 2, pp. 181-249. 
Martínez de Aguirre, Javier (2012), La Santa Cruz y el Santo Sepulcro: formas y espacios románicos, en Monumentos singulares del románico. Nuevas lecturas sobre formas y usos, Aguilar de Campoo, Fundación Santa María la Real, pp. 215-242.

McKiernan González, Eileen Patricia (2005), Monastery and monarchy: the foundation and patronage of Santa María la Real de Las Huelgas and Santa María la Real de Sigena, Austin, University of Texas (tesis doctoral).

Menéndez Pidal, Ramón (1969), La España del Cid, Madrid, Espasa Calpe.

Menéndez Pidal de Navascués, Faustino (1955), El blasón de la vila de Cintruénigo y las armas de Sobrarbe, "Hidalguía. La revista de Genealogía, Nobleza y Armas" 8, pp. 126-133.

Miranda García, Fermín (2011), Sacralización de la guerra en el siglo X. La perspectiva pamplonesa, "Anales de la Universidad de Alicante" 17, pp. 225-243.

Montaner Frutos, Alberto (1995), El señal del rey de Aragón. Historia y significado, Zaragoza, Institución Fernando el Católico.

Moralejo Álvarez, Serafín (1984), Un reflejo de la escultura de Jaca en una moneda de Sancho Ramírez (+1094), en Scritti di Storia dell'Arte in Onore di Roberto Salvini, Florencia, Sansoni, pp. 29-35.

O'Callaghan, Joseph F. (2003), Reconquest and Crusade in Medieval Spain, Filadelfia, University of Pennsylvania Press.

Oikonomides, Nicolas (1985), Byzantine Lead Seals, Washington D.C., Dumbarton Oaks.

Oliván Baile, Francisco (1969), Los monasterios de San Juan de la Peña y Santa Cruz de la Serós (Huesca). Estudio histórico-arqueológico, Zaragoza, El Noticiero.

Peñart Peñart, Damián (2002-2003), Episcopologio de Huesca, “Aragonia Sacra" $16-17$, pp. 59-87.

Pérez González, Maurilio (1997), Crónica del emperador Alfonso VII, León, Universidad de León.

Poza Yaguie, Marta (2000), El conjunto relicario de San Miguel de Villatuerta, en Bango, Isidro G. (dir.), Maravillas de la España Medieval. Tesoro sagrado y monarquía, León, Junta de Castilla y León - Caja España, vol. I, pp. 609-627.

Puertas Tricas, Rafael (1975), Iglesias hispanas (Siglos IV al VIII). Testimonios literarios, Madrid, Ministerio de Educación y Ciencia.

Ramírez Vaquero, Eloísa (1996), Bases de la simbología monetaria, en Signos de identidad histórica para Navarra, Pamplona, Caja de Ahorros de Navarra, pp. 159-174.

Reglà, Juan (1969), Història de Catalunya, Barcelona, Aedos. 
Rivero, Casto $\mathrm{M}^{\mathrm{a}}$ del (1955), La ceca musulmana de Córdoba y sus acuñaciones, "Numisma" 15, pp. 49-69.

Rodríguez de Lama, Ildefonso (1976), Colección diplomática medieval de La Rioja (923-1225). Documentos (1168-1225), vol. II, Logroño, Instituto de Estudios Riojanos.

Rodríguez Fernández, Justiniano (1966), Pedro Ansúrez, León, Diputación Provincial de León.

Royo Ortín, Marco L. (2008), La moneda en el reino de Aragón, "Numisma", www.numisma.org [consulta: 17/06/2013], pp. 39-115.

Ruether, Rosemary Radford (1969), Gregory of Nazianzus: Rhetor and Philosopher, Oxford, Oxford University Press.

Ruiz de la Peña, José Ignacio; Moralejo, José Luis (1985), Crónicas asturianas, Oviedo, Universidad de Oviedo.

Salrach, Josep Maria (1987), Història de Catalunya, vol. II, Barcelona, Edicions 62 .

Sánchez Albornoz, Claudio (1928), La primitiva organización monetaria de León y Castilla, "Anuario de Historia del Derecho Español" 5, pp. 1-46.

Sesma Muñoz, Ángel (2003), Aragón, los aragoneses y el Fuero de Jaca (siglos XI-XIII), en El Fuero de Jaca, Zaragoza, Institución Fernando el Católico, vol. II, pp. 197-225.

Silva y Verástegui, Soledad de (1980), Los primeros retratos reales en la miniatura hispánica altomedieval, "Príncipe de Viana" 160-161, pp. 257-271.

Silva y Verástegui, Soledad de (1984), Iconografía del siglo X en el reino de Pamplona-Nájera, Pamplona, Institución Príncipe de Viana.

Simon, David L. (2011), Art for a New Monarchy: Aragon in the Late Eleventh Century, "Anales de Historia del Arte" vol. extra 2, pp. 367390.

Soto Rábanos, José M. (1991), Introducción del rito romano en los reinos de España. Argumentos del papa Gregorio VII, "Studi Gregoriani”" 14, pp. 161-174.

Thomsen, Rudi (1956), Ensayo de sistematización de las monedas navarras y aragonesas de los siglos XI y XII. Estudio preliminar, "Numisma" 20, pp. 43-77.

Ubieto Arteta, Antonio (1948), La introducción del rito romano en Aragón y Navarra "Hispania Sacra. Revista española de historia eclesiástica" 1, pp. 299-324.

Ubieto Arteta, Antonio (1951), Colección Diplomática de Pedro I de Aragón y Navarra, Zaragoza, CSIC, Escuela de Estudios Medievales.

Ubieto Arteta, Antonio (1966), Cartulario de Santa Cruz de la Serós, Valencia, Anúbar. 
Ubieto Arteta, Antonio (1973), Los tenentes de Aragón y Navarra en los siglos XI y XII, Valencia, Anúbar.

Ubieto Arteta, Antonio (1986), Cartulario de Siresa, Zaragoza, Anúbar.

Ubieto Arteta, Antonio (1991), Los orígenes de los reinos de Castilla y Aragón, Zaragoza, Universidad de Zaragoza.

Vagad, Gauberto F. de (1996), Corónica de Aragón, edición facsímil de Carmen Orcástegui Gros, Zaragoza, Cortes de Aragón.

Valenzuela Foved, Virgilio (1959), Los monasterios de San Juan de la Peña y Santa Cruz de la Serós. Guía del visitante, Huesca, Instituto de Estudios Oscenses, CSIC.

Villaronga Garriga, Leandre (1987), Numismática antigua de Hispania. Iniciación a su estudio, Barcelona, Cymys.

Viruete Erzodáin, Roberto (2011), Aragón en la época de Ramiro I, Zaragoza, Universidad de Zaragoza.

Zacos, George (1984), Byzantine Lead Seals, ed. John W. Nesbitt, vol. II, Berna, Benteli Publishers.

Zurita, Jerónimo ([1562-1580], 1980), Anales de Aragón, Zaragoza, Institución Fernando el Católico.

Fecha de recepción del artículo: diciembre 2012

Fecha de aceptación y versión final: abril 2014 